\title{
JOHANN SAMUEL FRIEDRICH BOUBRIGI SÜNTAKSILOENGUD TARTU ÜLIKOOLIS
}

\author{
HELI LAANEKASK
}

Annotatsioon. Artiklis antakse ülevaade Tartu ülikooli eesti keele lektori Johann Samuel Friedrich Boubrigi süntaksiloengutest 1829. aasta kevadsemestril. Loengute sisu kirjeldatakse säilinud loengukäsikirja ning mitmete teiste arhivaalide põhjal, mida säilitatakse praegu Tartus Eesti Kirjandusmuuseumi Eesti kultuuriloolises arhiivis. Vaadeldakse ka loengutega seostuvat omaaegset keeleteaduslikku kirjandust, eriti August Wilhelm Hupeli teose „Ehstnische Sprachlehre“ (1818) süntaksipeatükki ning ajakirjas Beiträge zur genauern Kenntniß der ehstnischen Sprache avaldatud kirjutisi, aga ka eri teostes ilmunut.

Võtmesõnad: eesti keele uurimise ajalugu, eesti kirjakeele ajalugu, eesti keel sihtkeelena, eesti keele süntaks, eesti keele morfosüntaks

\section{Sissejuhatuseks}

Aastatel 1826-1837 töötas Tartu ülikooli eesti keele lektorina Johann Samuel Friedrich Boubrig (1788-1852). Boubrigi tegevust lektori ja keelemehena on tutvustatud mitmes varasemas kirjutises (nt Ariste 1979; Laanekask 2003, 2007, 2013). Riiast pärit Boubrig kahtles eesti keele lektori ametisse asudes, kas tema keeleoskus on piisav, ja püüdis seda täiendada muu hulgas oma sõbra, Räpina pastori ja tubli keelemehe Johann Friedrich Helleri (1786-1849) abiga. Vaidluses ühise eesti kirjakeele üle asus ta seisukohal, et nii tallinna kui ka tartu dialekt on eesti keel, tartu kirjakeele vägivaldset väljatõrjumist trükistest ta ei pooldanud. (Vt lähemalt Laanekask 2003, 2007.) Siinses artiklis tutvustatakse Boubrigi süntaksiloenguid Tartu ülikoolis 1829. aasta kevadsemestril.

Tartu ülikooli tolleaegsed eesti keele loengud olid mõeldud eelkõige teoloogiaüliõpilastele, kes oma tulevases pastoriametis pidid eesti keelt oskama nii kõnes kui ka kirjas. Suurem osa XIX sajandi algupoole Tartu teoloogiaüliõpilastest oli pärit Eesti- või Liivimaalt. Eesti keele varasem 
oskus oli neil siiski kõikuv, olenedes sellest, kui tihedalt ühes või teises saksakeelses peres eestlastega kokku puututi. Väljastpoolt eestikeelset ala pärit üliõpilased enamasti eesti keelt ei osanud (erandid, nagu Boubrig ise või Kristian Jaak Peterson - mõlemad pärit Riiast -, kinnitavad reeglit). Boubrigi loengute hoolas konspekteerija Wilhelm Julius Moritz (vt siin punkt 1.1) kuulus tõenäoliselt Liivimaa Moritzate pastorisuguvõssa ja oskas maakeelt ex usu arvatavasti juba enne oma stuudiumit (Laanekask 2013). Igal juhul õpetati eesti keelt tollases Tartu ülikoolis siht-, mitte emakeelena. Loenguid peeti saksa keeles.

\subsection{Käsikirjadest}

Boubrigi süntaksiloengute käsikirja „Zur Syntax der ehstnischen Sprache. Größtentheils in Folge der Angaben in Hupels Grammatik, 2te Ausg. von S. 121 an“ („Eesti süntaksist. Enamasti samas järjekorras kui Hupeli grammatika teises väljaandes sisalduv alates lk-st 121") säilitatakse Tartus Eesti Kirjandusmuuseumi Eesti kultuuriloolises arhiivis. Mustandliku manuskripti ${ }^{1}$, mis sisaldab 66 kvartformaadis lehte, on Boubrig algselt kirja pannud üsna tõenäoliselt samal 1829. aastal, mil ta loenguid pidas. Ta ise pole käsikirja allkirjastanud, aga tema püstine keerunditega käekiri on sedavõrd iseloomulik, et kirjapanija isikus pole mingit kahtlust. Atribueeringut toetab ka see, et käsikirja tiitellehel on teises käekirjas ja teise tindiga kirjutatud märge „v. Boubrig“ (s.t Boubrigilt). Daatum puudub, kuid käsikirja koostamise aega aitavad määrata temaga seotud arhivaalid.

Nimelt on Boubrig oma süntaksiloengute koostamisel suuresti toetunud Johann Friedrich Helleri käsikirjalistele märkmetele eesti süntaksi kohta, mille autor on dateerinud ja nimemärgiga $H$. allkirjastanud jaanuaris-veebruaris 1829; seda manuskripti (Heller 1829) säilitatakse samas arhiivis. Oma loengutes on Boubrig küll korduvalt ja ilmse poolehoiu ning lugupidamisega viidanud Helleri trükis ilmunud töödele, kuid sellele käsikirjale mitte.

Boubrigi lauseõpetuse kohta on lisaks säilinud ka ühe tubli tudengi loengukonspekt: õppeaastal 1828-1829 on tollane Tartu teoloogiaüliõpilane Wilhelm Julius Moritz (1808-1886) kuulanud Boubrigi eesti keele loengukursust ja teinud korralikke ülestähendusi, mida samuti säilitatakse kirjandusmuuseumis. Selle konspekti esimese osa põhjal (Moritz: 1-38p)

1 Siinses artiklis viidatakse sellele lühendiga B ja Hupeli grammatikale lühendiga H. 
on varem tutvustatud Boubrigi ülikooliloenguid 1828. aasta sügissemestril (Laanekask 2013). 1829. aasta kevadsemestril kirja pandud konspektiosa tiitellehel seisab: „Ehstnische Sprachlehre II. Syntactischer Theil nach Boubrig. Dorpat 1829. W. Julius Moritz, Stud. Theol.“ (Moritz: 39) Järgneval, täpsustaval lehel (lk 40) öeldakse veel: „Ehstnische Syntax, Zusätzen und Bemerkungen zu Aug. Wilh. Hupel's Ehstnischer Sprachlehre, 2te Auflage, Vierter Abschnitt, pg.121-144. Vorgetragen von Boubrig, 1829, Istes Sem.“ (Moritz: 40). Konspekt lõpeb dateeringuga „D. 1. Junius 1829“. (Moritz: 64p)

Huvitaval kombel on Boubrigi süntaksiloengute käsikirjast olemas ka käsikirjaline puhtandkoopia. See leidub kvartformaadis käsikirjaköites, mis kannab just sama pealkirja kui Boubrigi süntaksimanuskript (vt Zur Syntax: 1). Eesti kultuuriloolise arhiivi kartoteegis on see köide Helleri nime all, kuid tegelikult sisaldab see peale Boubrigi loenguteksti koopia (lk 1-81p) teisigi tekste, millest vähemalt osa on Helleri süntaksimärkmete (Heller 1829) puhtandkoopiad; leidub ka mõni leht Helleri käekirjas (Zur Syntax: 115-118) ja Boubrigi märkusega samas (Zur Syntax: 115). Koopiaköites on 120 lehte; ümberkirjutaja isik ootab veel selgitamist. Esilehel leiduva märkuse „an den verstorb. Propst Heller, zu Rappin“ ('surnud praost Hellerile, Räpinas') põhjal võiks ehk oletada, et selle koopiakogu on lasknud koostada Boubrig oma sõbra ja eesti keele teejuhataja Helleri jaoks (või mälestuseks hiljemalt pärast tolle surma 1849). Koopia ortograafia on originaalidega võrreldes küll veidi tänapäevasem ( $a e>\ddot{a}$, ey $>$ $e i$ jts). Et midagi kindlat väita, vajab asi veel täiendavat uurimist. Igatahes on kauni ja selge käekirjaga koopia olnud abiks Boubrigi süntaksiloengute kohati üpris mustandliku käsikirja väljalugemisel.

\subsection{Siinse artikli sisust}

Süntaksiloenguid pidas Boubrig ühe tunni nädalas (B: 5-5p). Teine nädalatund oli pühendatud praktilistele harjutustele, mis arvatavasti kujutasid endast eestikeelsete teoste lugemist-tõlkimist ja grammatika ning sõnatähenduste kommenteerimist (B: 6-8). Järgnevas tutvustatakse Boubrigi süntaksiloenguid, kusjuures kõrvale jäetakse Boubrigi teksti täpsem võrdlus Helleri märkustega ja Moritza konspektiga. Moritza konspekti on küll vaadatud, et näha, kas Boubrigi suuline ettekanne on enam-vähem vastanud tema loengukäsikirjale. Helleri süntaksimärkmeid 
ja nende lähedast suhet Boubrigi käsikirjaga tasub vaadelda kunagi hiljem eraldi.

Siinses artiklis jääb käsitlemata ka Boubrigi käsikirja lõpuosa: tolleaegsetes grammatikates traditsiooniliselt leiduv poeetikaõpetus „Einige kurze Bemerkungen in Beziehung auf die Poesie der Ehsten“ („Mõned lühikesed märkused eestlaste poeesia kohta“; B: 62-66, vrd H: 144-146). Moritza konspektis muide luulekäsitluse osa puudub. Samuti ei vaadelda siin Boubrigi kirjutist pealkirjaga ,Vorwort zu den practischen Uebungen im Ehstnischen“ („Eesti keele praktiliste harjutuste eessõna“), süntaksiloengute vahel olevat allkirja ja daatumita, kuid täiesti kindlalt Boubrigi iseloomuliku käekirjaga eraldi manuskripti, mille omaaegne arhivaar on korraldanud-pagineerinud süntaksiloengutega kokku (B: 6-8). Ka selle eessõna kohta Moritza märkmed puuduvad. Nii poeetikaõpetus kui ka praktiliste harjutuste sissejuhatus väärivad kumbki omaette tutvustamist.

Juba loengukäsikirja pealkirjast ilmneb, et Boubrig on oma õpetuse üles ehitanud otsekui kommentaarina August Wilhelm Hupeli grammatika 2. väljaande (1818) süntaksiosale (H: 121-144). Ta vaatleb seda enamvähem järjest, kusjuures Hupeli teksti ta oma käsikirjas ei tsiteeri, vaid üksnes nimetab kommenteeritava lehekülje, peatüki või lõigu. Võib-olla esitas ta vajaliku kirjakoha loengul või siis lugesid kuulajad seda raamatust ise. Moritza konspektiski on Hupeli seisukohad märgistatud ainult asjakohaste numbritega. Siinses tutvustuses tuleb arusaadavuse huvides ka Hupeli seisukohti lühidalt refereerida. Neid Hupeli grammatika üksikuid lõike, mida Boubrig pole kommenteerinud, siinses ülevaates enamasti ei kirjeldata. Küll aga on mõnikord olnud vajalik kommenteerida neid allikaid, millele Boubrig kas toetub või polemiseerides viitab. Boubrigit ja teisi refereerides on püütud säilitada omaaegset terminoloogiat (lisades seletustena nüüdisaegseid vasteid) ja näidete ebajärjekindlat ortograafiat, sh kohatisi diakriitilisi märke (nt kaldkriips vokaalil pikemat kestust märkimas, punkt vokaali all kas järgnevate konsonantide palatalisatsiooni osutamas või selleks, et näidata vokaali erinevat hääldust tallinna ja tartu keeles). Üksnes näidete suurt-väikest algustähte ning näidete vahel olevaid kirjavahemärke (punkt, koma, semikoolon, mõttekriips) on veidi ühtlustatud. Ka on korrigeeritud mõni väiksem näpuviga. Boubrigi jt poolt eesti näidetele sageli (kuid mitte alati) lisatud saksakeelseid tähendusseletusi on edastatud-tõlgitud valikuliselt, sisust lähtudes. Tuleb nimelt arvestada, et tegemist on saksa-eesti kontrastiivsüntaksiga, kus lähtekeeleks on just 
saksa keel ning kus sageli selgitatakse seda, kuidas üht või teist saksa keele tähendust tuleks „ehtsas eesti keeles“ edasi anda. Et tegemist on materjali esmatutvustusega, on püütud Boubrigi loengute sisu esitada võimalikult üksikasjalikult, seadmata tingimata eesmärgiks hinnangute andmist õige-vale skaalal nüüdisteadmistest lähtudes. Sel kombel loodetakse asjahuvilisele lugejale anda ettekujutus eesti keeleteaduse innukatest algusaegadest, võimaldada sissevaadet tollase eesti lauseõpetuse probleemidesse ja mõistete kujunemisloosse.

\section{Boubrigi süntaksiloengute sissejuhatus}

Sissejuhatuses (B: 2-5p) nendib Boubrig, et rohkem kui kunagi varem saadakse praegu aru sellest, et eesti keele grammatika on enamasti veel läbi uurimata ning vajab arukat ja hoolikat analüüsi. Eriti kehtivat see eesti süntaksi kohta: vanemates grammatikates selle kohta kirjutatu pole kuigi mainimisväärne, pigem kasutu. Selle asemel, et tutvuda eesti keele olemusega ja ammutada õigeid sõnaseadmisreegleid keelest endast, on eesti keelele sageli püütud peale suruda teiste, eriti ladina ja saksa keele reegleid. Sel kombel on Boubrigi arvates puudujäägid ning segadus keelekasutuses aina hullemaks muutunud. Ta peab eriti kahjulikuks vahepeal avaldunud püüet näha varasemat grammatilist ühekülgsust ja keelevigu hoopis otsekui midagi täiuslikku, millest ollakse taganetud ja mille poole peaks uuesti püüdlema. Veel hullem on tema meelest aga seisukoht, et eesti keele pärast ei tasuvat üldse muretseda ega lärmi lüüa: eestlane on ju sakslasi siiani ikkagi alati mõistnud, järelikult oskavad sakslased eestlase keelt piisavalt hästi. Boubrig ütleb, et just selliste vildakate arusaamade tõttu kubisevad tolleaegsed eesti raamatud ränkadest eksimustest puhta ja ehtsa eesti keele vastu. Paraku leiduvat ikka ja jälle neid, kes suhtuvad rahututesse kurtjatesse üleolekuga, arvates, et nad ise on eesti keele tõesti täielikult omandanud. On aga ka neid, kes peavad teisi eesti keelega tegelejaid rumalaks, selliseks, kes isegi keele algetest midagi ei taipa ning kes ei tohiks seetõttu rääkida süntaksist ega koguni keelefilosoofiast. Boubrigi seisukoht on, et eesti keel tuleb igal juhul ära õppida paljudel, kuna see on nende elukutse puhul ilmtingimata vajalik. Järelikult tuleb kasutu hädaldamine lõpetada: on vaja härjal sarvist kinni haarata ja vigu ning takistusi kõrvaldama asuda. Kui see ühel ei peaks õnnestuma, võib järgmine eksitustest õppida ja parema lahenduse leida. 
Igal juhul tuleks aga toetuda tõelisele keelefilosoofiale, sest just see on ainus kindel abimees nii raske ja keerulise stuudiumi juures. Eesti keele tarvis seni ülesseatud reeglid on Boubrigi sõnul ebafilosoofilised ja samas jäigalt pedantsed, keelekasutaja ei oska nendega midagi peale hakata; sellisel empiirilisel viisil konstrueeritud grammatika oleks mahu poolest võrreldav suurimate leksikonidega. Boubrig nendib, et kaasaegsete hulgas pole veel kedagi, kes suudaks juba praegu esitada üldkehtiva ja kindlalt põhjendatud eesti keeleõpetuse. „Kuid meie, teadusliku ettevalmistuse saanud haritud sakslased, oleme need, kes seda tööd unarule jätta ei tohi; me peame käed külge lööma ja tegema, mida suudame, kuni saabub aeg, mil võidakse teha rohkem, " ${ }^{2}$ õhutab ta.

Boubrig ütleb, et ta soovib pöörata tähelepanu eelkõige üldiselt kehtivatele põhiseisukohtadele. Ka tahab ta võimaluse korral toetuda varasema uurimistöö viljadele. Loengute aluseks võtab ta Hupeli grammatika süntaksiosa, kavatsedes seda kommenteerida ja täiendada. Ta loodab, et tema kuulajatel on sellisest käsitlusest kasu:

„Minu südamesoov on, et te edaspidi, eesti keelt põhjalikumalt uurides, saaksite kõigist neist märkustest, mille seast ükski pole tehtud läbimõtlematult või kiirustades, just sellist kasu, mida keele jaoks on võimalik saada, ja et teie kord võiksite üles ehitada kindlama hoone sellele vundamendile, mis võib-olla on veel väga nõrk, kuid mida on rajanud paljud kindlasti hoole ja innuga.“

\section{Eesti süntaksi eripära}

Edasi vaatlebki Boubrig Hupeli grammatika süntaksiosa peatükist peatükki, lõigust lõiku. Selle esimene peatükk kannab pealkirja „Allgemeine Anmerkungen“ („Üldised märkused“). Hupeli algusväide, mille kohaselt eesti keele süntaksireeglid on enamasti samasugused kui muudeski Euroopa keeltes ning seetõttu vajavad käsitlemist üksnes eesti süntaksi erijooned (H: 121), on Boubrigi arvates läbinisti ebaõige. Boubrig ütleb, et eesti keel kui üks soome suguvõssa kuuluvaid keeli erineb vanadest ja uutest keeltest ka oma süntaksi poolest väga palju. Lektor arvab koguni, et kõige rohkem süntaktilisi sarnasusi on eesti keelel prantsuse keelega: näiteks verbi vahetu järgnemine subjektile; eitus kahe sõna abil, millest esimene paikneb enne verbi, teine, eitust tugevdav sõna aga verbi järel;

\footnotetext{
${ }^{2}$ Heli Laanekase tõlge siin ja edaspidi.
} 
sarnasusi leidub ka nimisõnade definitiivses ja indefinitiivses tarvitamises jm. (B: 10)

\section{Käände- ja arvuühildumine}

Hupel on nentinud substantiivi ja adjektiivi tavalist käände- ja arvuühildumist (H: 121), kuid on sel puhul teinud paar märkust. Esimeses neist (H: 122) mainib ta erandit esimese daativi [= alaleütleva] puhul, kus adjektiiv täiendina jääb heakõla tõttu sageli ilma käändelõputa -le, olles otsekui genitiivis: hea töle, mitte heale töle (ent siiski ka keikile asjadele, sellele targa jummalale). Samas säilitab teine daativ [= alalütlev] üldiselt oma lõpu: sel wisil, ommal ajal. Boubrig lisab kommenteerides, et ühildumine oleneb käändelõpu häälikkujust, põhisõna ja täiendi silpide arvust ning ka lauserõhust (B: 10-11). Ta kordab oma varasemate morfoloogialoengute seisukohta: eesti päriskäändeid ei moodustata mitte nii nagu ladina keeles, vaid sufiksite abil. Sufiksid koosnevad ühest-kahest konsonandist (nt $s$, $s t, l, l t$ ) või ühest silbist (nt le, se, he). Peenema eestlase kõrvus kõlavad kriiskava kakofooniana just silpsufiksid, kui need lisatakse nimisõnale ja igale selle ees olevale adjektiivile või adjektiivsele pronoomenile (nagu teadmatusest teeb mõnigi end vilunud eesti keele oskajaks pidav sakslane). Boubrig ütleb, et just heakõla tõttu jätab eestlane esimeses daativis [= alaleütlevas], ingressiivis [= sisseütlevas] jm silbilise käändelõpu vaid põhisõnasse ja loobub täiendi vastavast käändelõpust, eriti veel siis, kui täiendis oleks käändesufiksi lisamisel sama palju silpe kui põhisõnas. Boubrig on lugenud ühe kirja alguses olnud pöördumist Ausale Koolmeistrile, pimmedale Mälleto Janile, mis kõlab tema meelest halvasti isegi sakslase kõrvus; ime veel, et seal ei seisnud Mälletumale, ironiseerib ta. Positiivse näitena esitab lektor praost Masingu (s.t Otto Wilhelm Masingu) ühe läkituse alguse: Ausa koolmeistre, Mälleto Janile. Täiendit ei tohi Boubrigi sõnul lühendada vaid siis, kui sellele langeb eriline rõhk: ta üttel ommile jüngrile, s.t nimelt oma, mitte nt Johannese jüngritele. Kui täiendsõna on rõhutus positsioonis, siis pole käändelõppu vaja: ta üttel omma jüngrile. Meieisapalves seisab rõhutatuna: ommile süüdleisile. Boubrig nendib, et eesti keel siiski võimaldab täiendsõna silpsufiksit ka siis, kui täiendis on põhisõnaga võrreldes rohkem silpe, nt ommale male. Konsonantidest koosnevad käändelõpud aga lisatakse Boubrigi väitel nii põhi- kui ka täiendsõnale. Kuid tallinna dialektis kasutatakse siiski sageli 
vorme, nagu omma poolt, omma kassuks, mitte ommalt poolt, ommaks kassuks. Siin viitab Boubrig Beiträge 13. vihikus lk 148 leiduvale lõigule (vrd Rosenplänter 1821), kus on käsitletud sõna omma ühildumist nimisõnaga. Boubrig arvab, et käändelõppude puudumise põhjuseks pole siin mitte heakõla taotlus, vaid see, et omma saab kasutada ka substantiivina, mis seega jääb genitiivi.

Hupeli teine märkus (H: 122) on arvuühildumise kohta. Ta ütleb, et mõnikord on adjektiiv ainsuses, kuid substantiiv mitmuses, nt keige asjade ots; mõnikord öeldakse aga ka keikide või keige innimestega. Kuid ainsuses oleva sõna rahwas 'Volk' puhul on mõnikord adjektiiv mitmuslik. Siin esitab Hupel näite piibli Ap 28: 2 ja 4 tollasest tekstist: umkeelsed rahwas 'das Volk von fremder Sprache' (vrd Piibel 1739). Ta ütleb, et sõna rahwas tuleks siin käsitada mitmuslikuna, tähenduses 'Leute'. Boubrig möönab, et tõepoolest mõeldakse selle sõna puhul rohkem üksikutele indiviididele kui tervikmassile. Kuid Boubrigit ei rahulda Hupeli märkuse algusosa väljendusviis, mis polevat kooskõlas keelefilosoofiliste [= üldkeeleteaduslike] põhimõtetega. Lektori arvates on vale öelda, et eesti keeles on võimalik mitmusekäändes nimisõna koos ainsusekäändes täiendiga. Õige tõlgendus on, et täiendsõna käändesufiksid jäävad ära just eufoonia tõttu, nii et kääne taandub algupärasesse relatiivi [= genitiivi]. Seda esineb eriti pikemates ühesuguse kõlaga fraasides ja sagedamini tallinna kui tartu kirjakeeles, sest tallinna keele mitmusevormid on tihti ebaharilikult pikad; rahvakeel on mõlemas dialektis vabam. Boubrig väidab, et tallinnaeestlane ei ütle mitte ommadel wannemattel, vaid omma wannemattel; tartueestlane aga omma wannambil. Eriti lühendatakse nii sõnu omma ja kõik. (B: 11-11p)

\section{Arvsõnade kasutamine}

Põhiarvsõnu kasutatakse Hupeli sõnul peaaegu alati ainsuses; kui nad on nominatiivis või akusatiivis [= partitiivis], siis on nende juurde kuuluv substantiiv akusatiivis, muidu aga on põhiarvsõna ja nimisõna samas käändes, $\mathrm{nt}$ tln kaks meest, trt kats meest; tln kahhe päwa pärrast, trt katte päiwa perrast (H: 122). Boubrig täiendab: indefinitiivis [= partitiivis] on eranditult kõik nimisõnad, mis kuuluvad definitiivis [= nominatiivis] olevate põhiarvsõnade ja ka kõikide teiste kvantiteeti näitavate sõnade (paljo, weidi, paar jne) juurde, nt kaks meest, wiiskümmend kaks luggemist. Tema 
meelest ei tundu see nii kummaline, kui mõelda, et nii soovitakse väljendada vaid üldisust sellele loomuomases määramatuses. Ka saksa keeles öeldavat mõnikord harvem zwey Mann või fünf Loof. Obliikvakäänetes ja ka indefinitiivis käänatakse Boubrigi väitel nimisõna aga alati koos arvsõnaga, nt katte (kahte) meest om (on) waja. Arvsõna käändesufiks jäetakse tavaliselt siiski ära. Siinkohal esitab Boubrig näitena rahvasuust kuuldud väljendi (praeguse kaasaütlevaga, mis tänini käändes ei ühildu): teekond on läbitud katte karaga, s.t kahe kaeraga, hobusele kaks korda kaeru söötes. Ta märgib ära ka sõnajärje tähenduse: põhiarvsõna nimisõna ees tähendab kindlat hulka (mul on kolm tuti 'ich habe 3 Griest'), nimisõna järel aga ebamäärast (mul on tuti kolm 'ich habe etwa, ungefähr 3 Griest'). (B: 11p-12)

Järgmisena on Hupel käsitlenud arvsõnade kasutamist aja ning vanuse väljendamisel. Ta räägib põhiarvsõnadest väljendites, nagu kel on kolm, kel pool neli, ma tullen kel kuus või peenemalt ma tullen kella kue aial. Harva kasutatakse järgarvsõna: ma tullen kuendamal tunnil. Ka vanust väljendatakse põhiarvsõna abil nagu saksa keeleski, kuid substantiivi asemel lisatakse arvule meelsasti adjektiiv: ta on kue näddaline, ma ollen kolme-kümne aastane. On aga võimalik öelda ka nagu saksa keeles: ma ollen kolmkümmend aastat wanna; peenem väljend on järgarvsõnaga: kolmas-kümnes aasta on mul kä. Kirju kirjutavad Hupeli sõnul vaid üksikud eestlased, kirju dateerida võib mitmel viisil, kas või nt kirjotud selle heina ku kuendamal päwal. (H: 122) Boubrig esitab lisaks väljendid, nagu tln kello kaks 'grade um 2 Uhr' ning trt kella katte aegu 'um 2 Uhr' ja ajul sama 'zur rechten Zeit ankommen'. Ta ütleb, et vanuse väljendamiseks kasutab eestlane sageli just jooksvat ajavahemikku, nt täl om kolmas näddal, ku, ajastaig pääl (viimane sõna võib ka ära jääda), ta käüp seitsmet aastat ja eriti kaunisõnaliselt ta om seitsmet aastat käüman. Ka Hupeli näidet kolmaskümnes aasta on mul kä (viimane vorm on Boubrigi arvates lühend inklusiivist [= seesütlevast] käes, trt käen) tuleks tõlkida 'ich bin im 30ten Jahr', mitte aga 'ich habe das 30te Jahr', nagu oleks kolmekümnes eluaasta juba täitunud. Daatumi väljendamise kohta ütleb Boubrig, et kuna eesti kuunimetused on väga kohmakad, kasutavad kirju kirjutavad eestlased enamasti juba ladinapäraseid vasteid. Harjumuspärast kommet kasutada daatumis sõna sel peab Boubrig täiesti valeks, hästi ei meeldi talle ka Masingu Marahwa Näddala-Lehhe dateeringud, kus sõna kú ees olev kuunimetus ei ole relatiivis [= genitiivis]: 3dal September-kú. Ta 
ütleb, et lühem ning mugavam on 3dal Septembril; kohanime võib lisada inklusiivis: Rias, Tartus. Dateerida võiks ehk ka eesti kuunimetusega: 3 dal Mihkli kuul, s.t 3dal päiwal, Mihkli kuul. (B: 12-13)

\section{Käänd- ja tegusõnade ühildumine}

Hupel väidab, et nimisõna ja tegusõna ühilduvad arvus, kuid esitab ka mõne erandi. Sõnade rahwas, hulk ja veel mõnegi samasuguse puhul võib verb olla nii ainsuses kui ka mitmuses: rahwas sööb 'das Volk isset', rahwas sööwad 'die Leute essen'. Ka on võimalik nii se rahwas kui ka need rahwas, ning piiblikoht kui rahwas sedda kulis, ehmatasid (Mt 22: 33) pole Hupeli arvates viga. Koos verbivormidega tulleb ja käib olevat sõna rahwas tavaliselt akusatiivis: rahwast tulleb 'das Volk kommt'. (H: 122) Boubrig möönab, et põhireegel kehtib nii tallinna kui ka tartu dialektis. Näite need rahwas puhul viitab ta oma varasemale kommentaarile sõna rahwas võimaliku mitmusliku, üksikindiviide märkiva sisu kohta. Verbi mitmusevormi põhjus on lektori meelest sama: perre söwa 'die Hausleute essen', sest peetakse silmas kõiki üksikisikuid. Ainsuslik verbivorm aga väljendab üldist tervikhulka: Kamtsatka rahwas on üks waẹe rahwas ja surem perre om iks rõomsam. Sõna hulk puhul kahtleb Boubrig verbi mitmusevormi kasutamises, sest ehtsas eesti keeles tähendab see sõna just seda üldist tervikut. Hupeli märkus näite rahwast tulleb asjus on Boubrigi arvates vales kohas ja valesti tõlgitud, õige tähendus on indefiniitne: 'es kommt Volk, es kommen Leute', samuti nagu nt väljendi wet josep tähendus on 'es fließt Wasser', mitte 'das Wasser'. (B: 13-13p)

Pelgalt fraseologismidena on Hupel tõlgendanud väljendeid issad ja emmad ellus 'ema ja isa elavad veel', ta on minnoga ühhe wannused 'me oleme ühevanused' (H: 122-123). Boubrig ütleb, et vähemalt tartu keeles on sellised fraseologismid tundmatud, ja peab neid igal juhul vigaseks ning ebasoovitavaks (B: 13p-14).

Hupeli järgi ei nõua sidesõnad ja, ning (trt nink), et nendega seotu oleks samas käändes või arvus. Ta on sel puhul viidanud piiblitekstile Js 53: 9 ilma tsitaati lisamata (H: 123). Boubrig on Hupeliga samal arvamusel, kuid tsiteerib ja kommenteerib oma kuulajatele näidet Ja temma on ö̈laid pannud ta haua jure, ja ühhe rikka temma surma jure, kus öälaid on mitmuses ja ühhe rikka ainsuses. Boubrig nõustub ka Hupeli samas toodud piiblinäitega (Srk 11: 17) selle kohta, et sidesõnadega ja 
või ning ühendatud ainsuslikud substantiivid ei nõua alati mitmuslikku verbivormi: hea ja kurri, ello ja surm, rikkus ja waesus tulleb issanda käest. (B: 14)

\section{Sõnajärg}

Hupel ütleb, et eesti keeles on sõnade järjekord sama loomulik kui saksa keeles. Ta esitab näitena lause Selig ist der Mann welcher dem Feinde nicht böses mit bösen vergilt ja selle eesti vaste Õnnis on se mees kes waenlasel kurja kurjaga ei tassu koos variandiga .. ei tassu mitte kurja kurjaga. Eesti ja saksa keele erinevusena märgib ta viimases variandis esinevat tendentsi paigutada verb käändsõna lähedusse. Selle põhjuseks peab ta eestlase laiskust või rumalust. Hupel esitab näiteid ka võimalike vabaduste kohta eesti keeles: saksa $d u$ giebst mir das Leben võib eesti keeles olla kas sa annad mulle ello, mulle annad sa ello või ello annad sa mulle. Suuremat täpsust harrastatavat vaid vääritimõistmise vältimiseks: anna ärra 'gieb weg' ja ärra anna 'gieb nicht'. (H: 123) Boubrigi arvates on sõnajärje puhul eestlaste laiskusest või rumalusest rääkimine täiesti kasutu ja isegi naeruväärne: neil omadustel pole mingit seost keele iseärasuste ega ülesehitusega. Ta ütleb pilgates, et kui Hupeli põhjendus peaks paika, siis peaksid ju prantslased, kelle keeles verb on veelgi rohkem eesasendis kui eesti keeles, olema eestlastest veel palju laisemad ja rumalamad. (B: 14p)

\section{Eitus}

Põgusalt on Hupel rääkinud eitusest eesti keeles. Tln ei ja trt es asetsevad tema sõnutsi kas päris lause alguses või igal juhul enne verbi: ei sa keik rikkaks või keik ei sa rikkaks 'nicht jeder wird reich' (H: 123-124). Boubrig ütleb selle kohta, et genuiinses või igapäevases keeles võivad $e i$ ja es paikneda ka pärast verbi, nt küsimusele vastamisel tulle ei 'er kommt nicht', tulle es, tulle es temma 'er kam nicht'; seda aga ei tasu jäljendada. Lihtsamas rahvakeeles tugevdatakse eitust nii, et ei on nii verbi ees kui ka järel: ei tulle ei 'er kommt durchaus nicht'. Hupeli näitelausetes aga märgib sõnade järjekord erinevaid rõhuasetusi: ei sá kõik rikkaks 'es werden nicht Alle reich'; seevastu kõik ei sá rikkaks 'Alle werden nicht reich (sondern vielmehr arm)'. (B: 14p-15) 
Hupel on puudutanud ka mitme eitussõna kasutamist, mis on tema sõnul eesti keeles tavaline: minna ei tulle mitte (sõna-sõnalt 'ich nicht komme nicht'), ei minna ei tea. Ta ütleb, et viimane eitussõna ei pruugi tingimata järgneda vahetult verbile ja võib ka ära jääda: minna ei armasta tedda (mitte). Harva lisatakse lausesse veel kolmaski eitav sõna pole tähenduses ep olle: ei ma pole sedda mitte teinud, sõna-sõnalt 'nicht ich habe nicht dies nicht gethan'. Imperatiivi eitussõnad ärra, ärge jne asetsevad samuti verbi ees, teine eitussõna mitte verbi järel võib ka ära jääda: ärra te sedda (mitte). Hupel väidab, et peenemaks rääkimisviisiks peetakse seda, kui ei paikneb ühendverbi osade vahel: kui ma teid wasta ei wõtta 'wenn ich euch nicht annehme'. (H: 124)

Boubrig ütleb rahulolematult, et eesti eitus kui väga omapärane ja mitmekesine nähtus väärib täpsemat käsitlust, kui on Hupelil. Lektor arvab, et eesti mitte on kas lühenenud ingressiiv [= sisseütlev] vormist middahe, mittahe või siis mingi ekstrakääne sõnast midda 'etwas'. Tegelik eitussõna on tema meelest ei, sõna mitte üksnes määrab eitust lähemalt, nagu ka sõnad middagi, suggugi jts. Taas võrdleb Boubrig eesti keelt prantsuse keelega: samasugused kahest sõnast koosnevad eitused on ne pas 'ei' (sõna-sõnalt 'nicht eine Schritt [ei sammugi]'), ne rien 'nicht etwas [mitte midagi]', ne point 'sugugi mitte' (sõna-sõnalt 'nicht einen Punct [mitte punktigi]'). Huvitavaks peab ta, et prantsuse ne ei või lauses esineda ilma verbita, eesti ei aga küll; prantsuse ne on harva ilma sõnata pas, eesti ei aga sageli ilma sõnata mitte, nimelt siis, kui tegemist on lihtsa, rõhutamata eitusega: minna ei tulle mitte on rõhutatud 'ich komme durchaus nicht', nagu ka ma ei tulle suggugi mitte 'ich komme auf keinen Fall', aga ma ei tulle on lihtsalt 'ich komme nicht'. (B: 15)

Hupeli näidet ei mina ei tea tuleks Boubrigi arvates samuti tõlgendada kui tugevdatud eitust, kus rõhk on just isikul: kuidas mina seda teadma pean, mina ei tea. Boubrig esitab samasuguseid näiteid rahvasuust: $e i$ minna sedda es ütle 'ich habe das ja nicht gesagt', ei sinna es wõtta sedda? 'du hast es doch nicht etwa genommen?'. Hupeli näidet ei minna polle sedda mitte teinud seletab Boubrig kui kolmest eitusest koosnevat: esimene $e i$ käib isiku kohta, teine (sõnas pole $=e p$ olle $=e i$ olle sisalduv) verbi kohta ja kolmas, mitte, tugevdab põhieitust 'ich habe das nimmermehr gethan'. (B: 15p) Boubrig mainib, et mõnikord algab eitus sõnaga egga (tekkinud arvatavasti sõnadest ei $k a$ ), millele alati järgneb teine eitus: egga minna sedda es ütle. Kahe eituse korral lisatakse mõnikord veel tugevdav sõna 
joht 'allerdings [igatahes]', mis paigutatakse viimase eituse ette: ta es ütle sedda joht mitte. Sõna kül eituse ees aga nõrgendab seda: ta es ütle sedda kül mitte 'er sagte das nun wohl eben nicht'. Kui mitte paikneb eituse ees, siis negatsioon tugevneb: mitte es lähhä temma 'er ging durchaus nicht', mitte ei pea sa sedda teggema 'du sollst es durchaus nicht thun'.

Imperatiivi eitava kõne puhul hoiatab Boubrig, et eitussõnu ärra, ärge ei tohi panna valesse kohta. Tallinnakeelses uues testamendis (UT 1815) ja tartukeelses vastses testamendis (WT 1821) on tema meelest tõlgitud täiesti vigaselt: tln olge wihhased, agga ärge tehke mitte patto ja trt wihhastellege, nink ärge patke mitte (Ef 4: 26), mille tähendus on Boubrigi arvates väär 'ihr sollt wohl zürnen, aber nicht sündigen [te peate küll vihastama, aga mitte patustama]'. Õigem olnuks tõlkida ärge olge wihhased, egga jne või ka omman wihhan (tln ommas wihhas) ärge tehke mitte patto. Veel mainib Boubrig (näidet toomata), et tartu keeles on imperatiivi 2. ja 3. isiku keeluvorm õigupoolest ühesugused. Tallinna keele pooldajad laidavad seda väga valeks, kuid samasugust nähtust esineb ka nt ladina keeles; senised eesti grammatikad seda ei kajasta. Boubrig hoiatab eitussõna ärajätmise eest, mida tehakse saksa keele eeskujul. See tekitab arusaamatusi, eriti veel siis, kui lõpust puudub ka sõna mitte, nt tln et ma woi tulla või trt et ta sedda woi tetta. Eriti suurt segadust tekitab see tartu keeles, kus preesensi ainsuse 1. isiku vorm on pöördelõputa ka jaatavas kõnes. Boubrigi arvates on kummaline, et selliselt kirjutab sageli isegi praost Masing. (B: 15p-16p)

\section{Kaassõnade ja rõhusõna küll paiknemine}

Hupel väidab, et genitiivne täiend (või mitu sellist) on alati substantiivi või muu juurdekuuluva sõna ees, nt meie sure jummala süddamelikko hallastusse läbbi. Prepositsioonide [= kaassõnade] kohta ütleb ta, et need paiknevad enamasti selle sõna järel, mille juurde nad kuuluvad. Kui kaassõna kuulub mitme sõna juurde, paikneb ta neist viimase järel, nt we ja tullega [komitatiivi ga-lõppu käsitati tollal kaassõnana]. Ainult kaassõnad wasto (tln), wasta (trt) ja läbbi võivad Hupeli väitel paikneda ka substantiivi ja selle juurde kuuluva possessiivpronoomeni vahel, nt $t a$ löi mo wasto silmi 'er schlug an meine (od. mir an die) Augen' (H: 124). Boubrig kommenteerib, et relatiivi [ = omastava] vormi $m o$ ei ole näites kasutatud mitte genitiivselt, vaid akusatiivselt (vormi mind asemel), seega 
ei ole siin tegemist kaassõna paigutamisega substantiivi ja genitiivse personaalpronoomeni vahele. Käänete süntaktilisi funktsioone oli Boubrig põgusamalt käsitlenud juba 1828. aasta sügissemestril oma morfoloogialoengutes, mille sisust võib aimu saada säilinud üliõpilaskonspekti põhjal (Moritz: 1-37; vt ka Laanekask 2013); siinsetes loengutes räägib ta asjast peatselt põhjalikumalt. Boubrig korrigeerib ka näite tõlget: silmi on siin kasutatud tähenduses 'nägu'. (B: 17)

Sõna kül on Hupeli sõnutsi tavaliselt eesasendis, seda nii põhitähenduses ('küllalt, piisavalt') kül jo või kül saab 'es ist genug', kül ma tean 'ich weiß es hinlänglich', aga ka tulevikku märkivalt kül ma tullen 'ich werde kommen' (H: 124). Boubrig täiendab, et kui järgneb tähendus 'aber', paigutab eestlane sõna kül meelsasti lõppu, nt ma tean sedda kül, ent või agga jne 'ich weiß das wohl, aber' (B: 17).

\section{Keelamine ja mahasalgamine}

Verbid käskma ja ütlema koos eitussõnaga ei või es väljendavad Hupeli arvates väga ilusasti keelamist või mahasalgamist, mittetunnistamist (lad nego), nt trt temma es kässe seddä kelleke ütteldä 'er verbot es irgend jemanden zu sagen', tln ei nemmad ütle üllestousmist ollewad 'sie läugnen die Auferstehung', trt ei ütle henda ollewat 'er läugnet daß er derselbe sey' (H: 124-125). Boubrig ei pea sellist väljendusviisi just väga ilusaks. Tema arvates on pigem huvitav, et tähendust 'verbieten [keelama]' väljendab eestlane negatiivselt väljendi 'nicht gebieten [mitte lubama]' varal ja tähendust 'leugnen [maha salgama, mitte tunnistama]' väljendi 'nicht sagen [mitte ütlema]' abil. Boubrigi meelest on selline väljendusviis väga ebamugav. Tuleks ju ometi vahet teha, kas a) ta ei ütelnud, et see olevat ('er sagte nicht, daß es sey') või b) ta ütles, et seda ei olevat ('er sagte, daß es nicht sey'). Eesti keeles aga oleks see mõlemal puhul temma es ütle ollewat, ja see ei meeldi Boubrigile. (B: 17-17p)

\section{Liitajad ja verb olema}

Hupel väidab, et abiverbi ollema ('seyn' või 'haben') eesti keeles üldiselt ära ei jäeta. Tõsi küll, öeldakse minna ei teinud sedda (tln, minna ei olle sedda teinud asemel), või ka es sa teddä woinu piddäda (trt, 'hättest du ihn nicht halten können'), aga sellistel puhkudel on tegu pigem imperfektiga, 
mitte perfektiga (H: 125). Boubrig oletab, et abiverbi ärajätmise korral võiks tegemist olla hoopis mingi erilise minevikuajaga, jutustavale stiilile omase tempus praeteritum historicum'iga, mida leidub nt Masingu teostes ja mis vajab veel lähemat uurimist. (B: 17p)

\section{Võrdlustarind mida .. seda}

Saksa väljendile je .. desto vastab eesti keeles Hupeli sõnutsi konstruktsioon sõnaga sedda (tln, trt) või seddä (trt), nt tln sedda surem sa olled sedda ennam allanda ennast 'je größer od. höher du bist desto mehr demüthige dich' (H: 125). Boubrig ütleb, et tartu keeles kuuleb sel puhul nii komparatsioonide kui ka pikemate lausete ühendamisel tavaliselt väljendit mis .. sedda, nt mis suremb, sedda kallimb (B: 17p).

\section{Saksa man-konstruktsiooni eesti vasted}

Viis võimalust on Hupel esitanud saksa umbmäärase man-konstruktsiooni edasiandmiseks eesti keeles: 1) pronoomeniga nemmad, nemmä, nt nemmad kutsuwad tedda 'man nennt ihn'; 2) kõige harilikumalt passiivi [= umbisikulise tegumoe] abil, nt tedda kutsutakse; 3) impersonaalselt ollema abil, nt on tunda 'man merkt od. fühlt', polle teäta 'man weiß nicht'; 4) sõnaga innimenne, nt innimenne willotab 'man friert'; 5) ainsuse 3. isiku abil, eriti eitavas kõnes, nt ei woi 'man kann nicht' (H: 125). Boubrig lisab, et kolmandas punktis on võimalik verbi olema äragi jätta, kui tegemist on hüüatuse või küsimusega, nt mis tetta! 'was ist da zu thun'. Boubrigi arvates on umbes samasugune umbisikuline konstruktsioon et + da-infinitiiv, nt et .. ellada, auustada jts Masingu raamatus ,Täieline Ristiusso õppetus ..“ (1826) lk 7, rida 13 jj. Veel ühe võimalusena saksa man'i väljendamiseks esitab Boubrig preesensi ainsuse 2. isiku kasutamise, kui kõneleja pöördub otsekui enda poole. See võivat algajat eksitada, olevat iseloomulik kõnekeelele, kuid mitte labane ega taunimisväärne. Boubrig toob mitu rahvasuust pärit näidet: mẹs sa teet? 'was soll man machen (was sollst du machen?)'; mes (sa) tälle teet? 'was ist mit ihm zu machen? (was thust du ihm?)'; tullet mõnnikõrd wälja 'man kommt wohl manchmal heraus (du komst wohl dann und wann zum Vorschein)' jne. (B: $17 \mathrm{p}-18 \mathrm{p})$ 


\section{Tähenduse 'liiga' väljendamine}

Saksa kvantiteediadverbide $z u$, zuviel väljendamiseks eesti keeles pakub Hupel sõna liaste (tln, trt), lijaste (trt) või ka komparatiivi, nt teie ollete liaste rikkad või teil on surem rikkus kui tarwis 'ihr seid zu reich', ta on on wäggewam mind 'er ist mir zu mächtig' (H: 125). Boubrigi arvates eestlasel õigupoolest puudub selline nn ultrakomparatiiv, mida saksa keeles väljendatakse sõnaga $z u$ ja prantsuse keeles sõnaga trop. Tema arvates lähtub eestlane sellest, mis oleks sobiv määr, parras, ja väljendab suuremat või silmapaistvat määra kas rõhutatud algvõrde abil või koguni säästlikult, ilma omadussõnata, nt $\underline{\text { ta }}$ on $p u$ ! 'see on üks õige, tubli, hiigelsuur puu'. Ka saksa keeles võidakse ju mõnikord samas tähenduses rõhutada: das ist ein Baum! Boubrig esitab lisanäiteid rahvasuust: wessi om lemmi, panneme külma (wet) mannu 'das Wasser ist zu heiß, wir wollen kaltes zugießen'; kot om rasse, mees jõwweto 'der Sack ist zu schwer, und der Mann ist zu schwach'; sedda om täl paljo 'das ist für ihn zu viel'; ta om kõrge, ma ei küni mannu 'das ist zu hoch, ich komme nicht an'; ma ollen temma wasto waene 'ich bin ihm zu arm', viidates sel puhul ka Helleri märkusele Beiträge 15. vihikus lk 112 (Heller 1822a). Boubrigi meelest ei sobi Hupeli grammatikas adverbi $z u$ väljendamiseks pakutu sugugi, sest 1) eestlane kasutab sõna lijaste või lijalt ainult koos verbidega (nt Ta waiwap henda lijalt), aga mitte koos omadussõnadega - viimane kasutusviis on Boubrigile ilmselt olnud tundmatu; 2) komparatiiv Hupeli näites teil on surem rikkus kui tarwis on üksnes kaudse, ümberütleva sõnastuse teenistuses ning 3) komparatiiv koos indefinitiiviga [= osastavaga] (wäggewam mind) väljendab üksnes võrdlust, mitte aga tähendust 'zu'. Ultrakomparatiivi väljendus oleks Boubrigi arvates ehk siiski eesti üllirikkas 'überreich'. (B: 18p-19)

\section{Maade ja rahvaste nimetamine}

Hupel ütleb, et Persia-ma on 'Pärsia', Persia-ma rahwas 'pärslased' ja Persia ma rahwas võiks tähendada 'Pärsia talupojad'. Just niisamuti on Eesti-ma 'Ehstland' ja Ehsti-ma rahwas 'die Ehsten [eestlased]' või 'Ehstländer [eestimaalased, Eestimaa elanikud]'. Hupel möönab, et väga tuntud rahvaste puhul võib sõna $m a$ ära jätta: wenne mees või wennelanne 'ein Russe', wenne rahwas 'die Russen [venelased]'; samamoodi Rootsi-ma 'Rootsi', rootsi naene 'rootslanna'. (H: 126) Boubrig rõhutab 
kõigepealt, et $m a$ tuleb igal juhul ortograafiliselt siduda maanimega, et ei tekiks liitsõna ma-rahwas [= 'eestlased'], ning märgib, et ehtsas eesti keeles on talupoegade kohta võimalik öelda veelgi täpsemalt: Persia-ma tallorahwas 'die persische Bauern, das persische Landvolk'; Lihwlandima tallorahwas 'die livländische Bauern'. Huvitav on kommentaar lanelõpuliste rahvanimetuste kohta: Boubrigi järgi on neil halvustav varjund. Viisakas keeles ei kasutata nt sõna Wennelane, vaid öeldakse Wennemees, wennenaẹne, wennepois, wennetüdruk, 'venelanna' on wennik; samamoodi ka Lättimees, Lättinaẹne jne. (B: 19p)

\section{Käändesüntaks Helleri ja Boubrigi järgi}

Hupeli grammatika lauseõpetusosa teine peatükk on pühendatud käändesüntaksile: „Gebrauch der Abfälle, und wodurch sie regiert werden“" („Käänete kasutamine ja see, millest nad sõltuvad“; H: 126-135). Boubrig oli eesti käändesüsteemi käsitlenud juba oma morfoloogialoengutes kevadsemestril 1828, toetudes põhiliselt Helleri kahele Beiträges ilmunud uuenduslikule artiklile (Heller 1822c, 1823) ning neis viidatud allikatele (nt Renvall 1815-1817; Stråhlmann 1816; Knüpffer 1817; Peterson 1818b, 1818c; Sjögren 1821), mida kõiki on ta soovitanud ka oma üliõpilastele (vrd Moritz: 24p-30p). Siinsetes lauseõpetusloengutes käsitleb Boubrig eesti käändesüntaksit põhjalikumalt, loobudes esialgu Hupeli vastava süntaksiosa raamistikust.

\subsection{Boubrigi käändesüntaksi taust: Helleri uuendused}

Helleri uuenduslikkus võrreldes varasemate eesti grammatikutega (nt Hupeliga) seisneb eelkõige arvamuses, et kolm seni tuntud käänet (nominatiiv, genitiiv ja akusatiiv) ei ole tõelised käänded, vaid pigem modaalsusvormid. Neid ei kasutata mitte niivõrd sõnadevahelise seose näitamiseks lauses, kuivõrd definiitsuse-indefiniitsuse märkimiseks, kusjuures eristatakse täielikult määratut (definitiiv), pooleldi määratut (relatiiv) ja määramatut, s.t üldse mitte määratut (indefinitiiv). Need kolm modaalsusvormi võivad olenevalt asjaoludest esindada kolme vana käände mitut funktsiooni, mida Heller ka kirjeldab. (Heller 1822c: 1-32; vrd ka Wiedemann 2011: 30, 40-41) Et need kolm vormi on aluseks teiste käänete moodustamisel, nimetab Heller neid konstruktsioonikääneteks 
(lad casus constructionales); päriskäänded (lad casus veri) on possessiiv [= alalütlev], daativ [= alaleütlev], ablatiiv [= alaltütlev], inklusiiv [= seesütlev], ingressiiv [ $=$ sisseütlev], egressiiv [= seestütlev] ja formatiiv ehk faktiiv [= saav]. Lisaks toob ta ära ka kolm postpositsioonkäänet (lad casus postpositionales): terminatiiv [= rajav], unitiiv, mis tema sõnul on osalt komitatiiv, osalt instrumentaal [= kaasaütlev], ning privatiiv [= ilmaütlev] (Heller 1822c: 32-36, 1823: 19). Adverbisufiksina on ta kirjeldanud praegust essiivilõppu -na, teisi selliseid sufikseid on -li, -tassa või -ltasa, -ti või -te, -si (Heller 1822c: 36-37); teisal on ta neid siiski nimetanud adverbiaalkääneteks (lad casus adverbiales), rõhutades ometi, et tegu pole päriskäänetega (Heller 1823: 19). Boubrigi morfoloogialoengutes esitatud käändesüsteem on olnud peaaegu samasugune, vaid adverbiaalkäänete puhul on väikseid muutusi (vrd Moritz: 28p ülevaatetabel).

Kõigepealt käsitleb Boubrig kolme konstruktsioonikäände süntaksit. Käsitlust alustades (B: 21) on lektor kohe viidanud Helleri artiklile (1822c), kust ongi pärit tema põhiseisukohad ja näidete enamik. Boubrigi käändekirjeldused on metoodiliselt hästi üles ehitatud, koosnedes põhireeglist ja selle juurde kuuluvatest täpsustustest.

\subsection{Definitiiv [= nimetav]}

Definitiivis on põhireegli kohaselt isik või asi, kes või mis on definiitne (määratud), s.t keegi või miski selline, kes või mis on kõnelejatele kas jutu või varem olnu kaudu või lihtsalt iseenesest nii tuttav, et vajab pelgalt nimetamist. Seejuures pole tähtis, kas määratu on subjekt või objekt; kõnes on rohkem see, mida isiku või asja kohta öeldakse, mitte isik või asi ise. (B: 20-21)

Täpsustavate reeglite kohaselt kasutatakse definitiivi

1) nominatiivselt: a) aktiivset tegevust märkiva verbi subjektina, nt temma kirjotab; b) neutraalset tegevust märkiva verbi subjektina, kui viimast käsitatakse iseseisvana või personaalsena, nt werri josep 'das Blut fließt'; c) topelt [= subjektina ja predikatiivina] koos verbiga ollema, nt Peter om weel lạts; Jummal on armolinne; innimesse omma ausama kui ellaja. Kuid koos verbiga ollema võib definitiiv esineda ka üksi, nt meie ollime koddun;

2) akusatiivselt, kui sõna on otsene verbirektsioon ehk objekt, mida kõnes ei rõhutata, sest objekt on juba määratud ja tuttav, nt temma 
kätte anti Jesaia ramat (Lk 4: 17); kohhes sa nemma pannit?; ma oppasi temma 'ich instruirte ihn'; pesse käed käskimata; ta tõstis ommad silmad taewa pole (Jh 17: 1). Siin on aga ka erandeid, kui kõnes on a) 1. ja 2. isiku personaalpronoomenid; b) verba sensuum (meeltetegevust väljendavad) -verbid ja kestvat tegevust näitavad verbid; c) eitused ja d) impersonaalne aktiivivorm ehk see, mida siiani on nimetatud passiiviks; viimase kasutusreeglid on Boubrigi sõnul võrreldavad infinitiivide süntaksi reeglitega; (B: 21p-22)

3) nominatiivselt ja akusatiivselt lihtsates põhiarvsõnades 1-10, ka siis, kui 1-9 kasutatakse suuremate arvude moodustamiseks. Erandiks on a) eitused, kus määratus kaob ja kus seetõttu kasutatakse indefinitiivi, nt ei olle seäl wiit, kuut, ei ka neljagi innimest; b) sõna üts ühildub oma nimisõnaga, kui ta on lauses tarbetuna või tähenduses 'ein gewisses [teatud]', nt temma küssib ühte/ütte rublat; (B: 22-22p)

4) vokatiivselt ja imperatiivselt 2. isikus, kuna pole võimalik, et kõnetatav oleks määramatu: Mehhed!; Anna, Jummal! Boubrig hoiatab: imperatiivi kolmandas isikus tuleb alati kaaluda, kas tegu on määratu või määramatuga. Ta ütleb, et siin tuleb hästi esile tavalise väite ,imperatiiv nõuab nominatiivi“" paikapidamatus: näites olgo se nüüd nida osutab se varem mainitule; näites et olgo sedda et peaks sõna sedda määratus alles järgnema. Definiitsuseindefiniitsuse avaldumist näeb Boubrig ka näidetes tulgo wihm lomukestele abbis (personifikatsioon, tegutsemine) või tulgo, sago wihma ehk põuda! (üldiselt, partitiivselt); se olgo (määratult) või sedda ärra olgo! (eitavalt, määramatuks muutunult); ka wõtta lạst kasa, (märastagi), s.t mingi laps, definiitselt aga lạts, s.t laps, kellest just juttu oli; (B: 22p)

5) hüüatustes ainsuse 1. ja 2. isikus, nt oh, minna waẹne!, samal ajal kui mitmus näib nõudvat indefinitiivi, nt oh, neid waessid! Ainsuse 3. isiku puhul tuleks vorm valida olenevalt definiitsusest-indefiniitsusest, nt imme! 'o dies Wunder!' või oh, sedda immet! 'ach, ein Wunder!'; oh, temma waẹne! 'ach, dieser Arme!'või oh, sedda waest! 'so ein Armer!'; (B: 22p-23)

6) perioodiliselt korduvate ajavahemike märkimiseks, nt $\ddot{o}$ ning päiw; egga näddal; eggakõrd; 
7) vormiga ollewat, kui see mingil viisil seostub lause subjektiga, nt Jaan haige ollewat (ütteldas) 'J. soll krank seyn'; se ma näis maddal ollewat; ta näis hea ramat ollewat; jõest kuultawat hölli 'vom Bache hört man ein Geschrey'. Vormid ütteldas ja kuultawat käituvad Boubrigi sõnul samuti nagu ollewat;

8) liitnimisõnades, kus esimene sõna on midagi teise juurde kuuluvat, või täpsemalt, kui esimene väljendab teise materjali (waskkattal, kuldpenning, raudsaạn), töövahendit (tuulkiwwi, weskkiwwi), toodet (kängsep, rätsep), sisu (tunnistuskirri, wõlgkirri), osa (nööpnõggel, korwwankre) või täpset klassifikatsiooni (kirjotuskamber). (B: 23; vrd ka Heller 1822c: 9-15)

\subsection{Relatiiv $[=$ omastav $]$}

Põhireegli järgi on relatiivis osaliselt määratud isik või asi. Boubrig seletab: kõnelejale isiklikult võib kõnealune olla tuntud ehk definiitne, kuulajale aga veel mitte; tegemist on relatiivse määratusega. Nimetus ,relatiiv“ on lektori sõnul õigustatud ka seetõttu, et see kääne liidab endaga mitmesuguseid sufikseid ja väljendab nii mitmelaadseid seoseid (relatsioone) asjade ja isikute vahel. Nominatiivselt ei kasutata seda käänet kunagi, akusatiivselt esineb ta vaid ainsuses, ja teatud konstruktsioonides on relatiiv ka genitiivne. (B: 23p, vrd Heller 1822c: 10)

Täpsustavate reeglite kohaselt kasutatakse relatiivi

1) akusatiivselt vaid ainsuses: kõneleja jaoks on tegu individuaalselt tuntuga, kuulaja teab kõnealusest üksnes liiki või üldmõistet, nt wõttis karrika (1Kr 11:25), 'den Becher', karika, mis seisis laual, teatud kindla peekri, mille ta ise oli välja valinud; teiste jaoks aga 'einen Kelch', mingi peekri. Samasuguste näidetena esitab Boubrig ka ma osti hobbose; kohhes sa weitse (noa) pannit 'noa, mis siin oli'; nemma teggiwa korsna maddala; piiblikoha kui temma se ramato lahti teggi .. kinni panni (Lk 4: 17, 20). Võimalik on ka preesens: ma tahhan hobbose osta 'juba väljavalitud hobuse'; weel ütte (ühhe) kõrra panne(n) peäle 'teen veel ühe kihi, mida ma juba olin kavatsenud teha'. Näidete hulgast leiame ka objektisarnase ajamäärusega piiblikoha: meie olleme kõige öö tööd tennu (Lk 5: 5), mis esitatakse veel kord 6. täpsustava reegli juures; (B: 23p-24; vrd Heller 1822c: 10, 15-16) 
2) genitiivselt ehk konstruktsiooniliselt (lad per constructionem): relatiivis nimisõna või personaalpronoomen seisab teise nimisõna ees ilma mingi lisanduseta, osutades, et teine kuulub tollele esimesele, nt issa lạts või neide poeg;

3) pärisnimedes või tiitlites, nt Lihwlandi-ma, Reili-Issand, KindraliHer;

4) heakõla tõttu: relatiivivorm võib tekkida käändelõpu ärajätmisel, nt omma jüngrile või kõige heä töle;

5) vormiga ollewat, kui kasutatakse imperfekti, nt ma näi(n) ütte penni, (ühhe koera,) ning mõtli(n) temma soe (hụndi) ollewat; ma arwsi (arwasin) temma waẹse ollewat; ta mõtles nisugguse kotti ollewat;

6) ühekordse ajavahemiku edasiandmisel, eriti imperfektis, nt meie olleme kõige öö tööd tennu (Lk 5: 5); ma olli(n) seäl ütte (ühhe) aasta, näddala; ta põddesi kõige suwwe, kus rääkija tunneb kõnesolevat aega lähemalt, kuulajale aga on see pelk ajavahemik;

7) koos sufiksitega muude kui konstruktsioonikäänete moodustamisel (siinkohal viitab Boubrig taas oma morfoloogialoengutele, vrd Moritz: 28);

8) liitnimisõnades määrava sõnana: kui teine sõna tähistab midagi esimesele kuuluvat, siis esimene, relatiivis olev, näitab nime, liiki, viisi, otstarvet, nt Ria liin, mõtsawaht, jowiko-marri, herne-terra, sängi-linna (erand: laudlinna), känga-rihm, kaddaja-suits, Kaarlinoor-herra, tobako-toos;

9) konstruktsiooni tõttu langevad tartu dialektis ainsuse relatiiv ja pluurali definitiiv kokku, märkides Boubrigi arvates seda, et tuntud asjad muutuvad mitmuses absoluutseks, nt mehhe lätsiwa; to ne ramato ärra;

10) koos mõne omadussõnaga (nt arwoline, sarnane jts), mis väljendavad seost relatiivis oleva sõnaga. (B: 24-25; vrd Heller 1822c: 16-20)

\subsection{Indefinitiiv [= osastav]}

Indefinitiivi põhireegel Boubrigil kõlab: indefinitiivi kasutatakse nominatiivselt ja akusatiivselt, ja nimelt siis, kui isik või asi on veel indefiniitne ehk kõnes määramata, s.t ei ole veel tuttav definiitselt, vaid üksnes üldiselt 
kui liik või partitiivselt kui mingisse liiki kuuluv; täpsem määramine saab toimuda alles hiljem. Et indefinitiivis olev sõna on tavaliselt lause tähtsaim, see, millele kõne on sihitud, siis on ta lauses enamasti rõhutatud. (B: 25; vrd Heller 1822c: 10-11)

Täpsustavas osas räägib Boubrig indefinitiivi kasutamisest

1) nominatiivselt, sealhulgas a) verbi ollema ja mõne laia sisuga verbi ebaisikulise, mitteiseseisva subjektina, kusjuures subjektiks olev sõna tähistab liiki, hulka või ainet ning on mõistetav üldisena või partitiivsena, nt weist (nugga) om waja; seäl olli rahwast, innimessi, kes jne; kül saab aega; seäl tulleb rahwast, söawägge; keldre tulli wet; tulli paisid ülles; näe, kui josep werd; saddab wihma, lund; sedda woip kül sada, sündida, et jne; siit käib tuult; b) samade sõnade (ja eriti saama, ollema) puhul veelgi rohkem siis, kui subjekti eitatakse, sest siis individuaalne otsekui kaoks, mõeldakse vaid üldisele, nt seäl ei olle wet; teid, meid es olle koddun; ei olle keddagi tarren; sia es sa wihma; ei tulle keddagi; ei olle perremeest koddun; ei olle Kaarli nätta; ei olle Peetrit kodduni; (B: 25-25p; vrd Heller 1822c: 20-22)

2) akusatiivselt: a) eitavates lausetes iga aktiivverbi otsese rektsioonina [= sihitisena]; b) jaatavates lausetes aktiivverbi otsese rektsioonina, kui ei ole eelistingimusi definitiivi või relatiivi jaoks. Siinkohal loetleb Boubrig ka verbe, mis eriti sageli nõuavad indefinitiivi: moraalse tähendusega, kestvat tegevust väljendavad verbid, nagu käskma, keelma, õpma, õppetama, awwitama, uskma, tennama, tenima, nt ma tahhan sedda; armasta Jummalat; ärra wihka sedda last; pelja omma wannambid; meeltetegevust väljendavad verbid, nagu nägema jts, mis samuti osutavad kestvale tegevusele; c) nn passiivis, mis pigem on impersonaalne aktiiv (näidet pole ta lisanud, kuid nii tema kui ka Heller on siin tõenäoliselt silmas pidanud umbisikuliste lausete partitiivset objekti, vrd Heller 1822c: 23); d) preesensi partitsiibi vat-vormis, mis väljendab kestvat tegevust ning on alati indefinitiivi ainsuses, olenemata subjekti või objekti arvust või käändest, nt ma näe tedda pimme ollewat; ma mõtle tedda seäl ollewat; ma kule hobbose ('die Pferde', hobbosid 'Pferde') tullewat; ma mõtli, reiwast jo kuiwa ollewat; ta näis must ollewat, mustas sawat, minnewat; mõttelge henda kül kolu ollewat, ent ellawat (Rm 6: 11). Boubrig 
arvab, et partitsiibi wat- ja wad-kuju on ilmselt samatähenduslikud, esitades viite Masingule, kes oli väitnud vastupidist (Masing 1824a: 31-32), ja Masingut kritiseerinud Wilhelm Friedrich Steingrüberile (1826: 32-33); e) akusatiivselt kasutatud isikunimed ja 1. ja 2. isiku personaalpronoomenid on alati indefinitiivis, nt teid, mind, Peetrit tahhawa nemma wastawõtta; f) sama kehtib ka kõigi kollektiiv- ja abstraktmõisteid tähistavate sõnade kohta, kui neid käsitatakse partitiivselt, nt ma toi sedda liwa, neid samblid seält otsast; to sedda liwa ärra; meie saime sedda lotust. Boubrig märgib, et individuaalse või personifitseeritud sisu korral võivad need sõnad muidugi olla ka apellatiivselt, definitiivis: se liiw teeb lubja mustas; se heä lotus pẹt meid; (B: 25p-27; vrd Heller 1822c: 22-25)

3) nominatiivselt ja akusatiivselt kõigis nimisõnades, mis oma mõõdu, arvu, kvantiteedi vms tõttu väljendavad partitiivsust. Sel puhul mõeldakse kvantiteeti jms kui midagi üldist, mitte kui individuaalselt määratut. Põhiliselt kasutatakse ainsust, nt nellitõistkümmend (neljatkümmend) wakka hääd semend omma jo wäljaantu, nü̈̈d lubba minna weel, nellitõistkümmend wakka seddasamma semend; ma osti wiistõistkümmend künart sinnist kallewat; paljo, weidi, suur hulk rahwast lätsiwa; mul om leiba kül; nelli innimest tulliwa paar waggo maad meie taggan (mitte pari, ütleb Boubrig, sest paar seisab põhiarvsõna kạts asemel); minna palle pool wakka wilja; wiis koormat puud või puid; mitto innimest; täis wet; üts sutäis wet. Eraldi seletab lektor veel sõnade üts ja pool kasutamist; (B: 27-27p; vrd Heller 1822c: 25-26)

4) komparatiivi järel, kui objectum comparationis on veel tundmatu või indefiniitne, nt ma ollen pikkem tedda 'ich bin größer, als er'; kui aga rõhk oleks tähendusel 'größer', siis öeldaks minna ollen temmast pikkem. Võrdlust sõna kui abil kuuleb küll sageli, kuid Boubrigi arvates on see saksapärane ja vale, sest kui tähendavat õigupoolest 'wie', mitte 'als';

5) hüüatustes, nt minno waẹst! 'wie arm bin ich!' (aga minna waẹne! 'ich Armer!');

6) mingile tegevusele kuluva aja väljendamisel, nt lạts tännitab ööd ning päiwa. Kui ajavahemik on tegevusega võrreldes pikem, kasutatakse aga possessiivi [= alalütlevat], nt sel aejal sündi, et jne; 
7) mõne pre- ja postpositsiooni rektsioonina;

8) kvantiteedisuhte väljendamisel mõnes üksikus liitsõnas, nt pissutassi 'pisiasi', ja

9) koos sõnadega wäärt, wärki, wisi jts, nt sedda wäärt. (B: 27p-28; vrd Heller 1822c: 26-27)

\subsection{Kokkuvõtvalt konstruktsioonikäänetest}

Boubrig ütleb, et konstruktsioonikäänete esitus ei olnud sugugi täiuslik, vaid vajab veel muutmist ja parandamist nagu kõik uued katsetused. Asi ise olevat keeruline, võib-olla üks raskemaid teemasid kogu eesti keele grammatikas, ning lähenemisnurk on olnud nii uudne, et peaaegu midagi vanades grammatikates leiduvast ei saanud kasutada. Lisaks leidub eesti keeles - nagu mis tahes keeles - erandeid ja anomaaliaid, mida on võimatu otsekohe ära tunda ja eritleda. Lektor toonitab, et uues suunas tasub tegutseda, sest esiteks põhineb see teooria keelefilosoofilisel meetodil, toetudes ometi ka empiirilisele teadmisele, ja teiseks on mitmed arukad eesti keele tundjad väljendanud peaaegu samasuguseid arusaamu. Boubrig toob näiteks Arnold Friedrich Johann Knüpfferi teooria määratusest ja määramatusest kahes eri deklinatsioonis (Knüpffer 1817) ning sünnipärase eestlase Kristian Jaak Petersoni kirjutised Beiträge 12. vihikus (Peterson 1818b, 1818c). Siinjuures kahetseb Boubrig, et Tartu ülikoolis studeerinud noormees liiga vara suri ja nii eesti keele grammatika jaoks kaduma läks. Lektor ütleb, et Helleri teooria uudsus on pigem esitusviisis: definiitsust-indefiniitsust nähakse igas käändes eraldi ja päris hästi põhjendatult. Seetõttu loodab Boubrig, et kogu asi end edaspidi ikka rohkem õigustab. Oponeeriva seisukoha näitena viitab ta anonüümsele artiklile Beiträge 17. vihikus (tegemist on Steingrüberi kirjutisega, kus teraselt kritiseeritakse mh mitut Knüpfferi ja Helleri seisukohta, vt Steingrüber 1825; atribueeringu kohta vt Laanekask 1988: 585-586). Boubrig ei vaatle loengus artikli vastuväiteid lähemalt, nendib vaid, et uues asjas võib olla vigu, mida edaspidi saab vältida. Ka tuletab ta oma kuulajatele meelde, et rahvas võib vahel rääkida ka valesti, olles mõjutatud eesti keelt ebaõigesti pruukivatest sakslastest ja nende poolt kasutatavast sageli lausa kahjulikust raamatukeelest.

Käändesüntaksi kohta käivana mainib Boubrig veel artiklit Beiträge 12. vihikus (see on Knüpfferi deklinatsiooniõpetuse tutvustus, vt 
Rosenplänter 1818) ja Masingu ortograafiabrošüüris leiduvat (Masing 1824a: 26 jj). Enda jaoks on Boubrig osa lõppu teinud märgendi edaspidiseks: siia paigutada uued teooriakäsitlused. (B: 28-30)

\subsection{Possessiiv ja daativ [= alalütlev ja alaleütlev]}

Ka päriskäänete (vt 16.1) süntaktilisi funktsioone oli Boubrig põgusamalt tutvustanud juba oma morfoloogialoengutes, millele ta ka siinses tekstis viitab (B: 30; vrd Moritz 28-30). Ta ütleb, et käänete rolli lauses näitavad juba nende nimed, samuti küsimused, millele käänded vastavad. Boubrig refereerib Masingu väidet raamatust ,Ehstnische Originalblätter“", tõlgendades seda nii, nagu oleksid Masingu arvates senised 1. ja 2. daativ (Helleril-Boubrigil possessiiv ja daativ [= alal- ja alaleütlev]) üsna sarnased ja seetõttu võiks Masingu arvates 2. daativist loobuda. Tõepoolest on Masing küll nentinud lõppude $-l$ ja -le eri funktsioone, kuid pidanud praeguse alaleütleva $e$-d üksnes kohamääratluseks (lad terminatio ad locum), mis vastab küsimusele wohin ('kuhu'); seda võivat pigem pidada akusatiiviks (lad accusativum directionis). Muus osas olevat $-l$ ja -le täpselt daativi funktsioonides (wo 'kus' ja wem 'kellele') ning seetõttu võiks neid pidada üheks käändeks (vrd Masing 1816a: 44-45).

Boubrig ütleb, et tegu on kindlasti eri käänetega, ja annab kõigepealt põhireegli kummagi tarvis. Possessiivi - $l$ osutab, et inimesel või asjal juba on midagi, daativi -le aga näitab, et midagi antakse kellegi või millegi kuuluvusse. Ühtlasi näitab possessiiv omamist rahuolekus, püsivuses, daativ aga alles omamise poole püüdlemist. Niisiis suuna mõttes tähistab possessiiv saavutatud sihtpunkti, vastates küsimusele „,kus?“, daativ aga suunda ennast, vastates küsimusele „kuhu?“. (B: 30-30p)

Täpsustavate reeglite kohaselt kasutatakse possessiivi

1) omamise näitamiseks, järelikult on selles käändes isik, olukord, aeg, koht, asi või tegevus, kellele või millele midagi kuulub või on antud, nt taẹwas om mürrinal 'der Himmel grollt'; mõts om kohhinal ja kahhinal 'der ganze Wald sauset und brauset'; järwel 'auf dem See'; teul 'in der Arbeit'; rehhel 'im Riegendreschen'; sel ajal 'in dieser Zeit'; sel kombel 'auf diese Weise'; sel päiwal jne;

2) passiivis väljendatud tegevuse algataja (sks 'Urheber') väljendamiseks, kui see tegevus on toimunud tema kasuks või mõjub tema 
omandusele - Boubrigi sõnul ehteestilik viis, nt se on $\underline{\mathrm{mul}}$ tettu 'dies ist für mich gemacht';

3) saksa tähenduse 'durch [poolt]' väljendamiseks, nt ma lasse sedda palgaleisil tetta 'ich lasse dies durch Tagenlöhner thun'; lasse Kaarlil üttelda 'laß durch den Karl sagen'; se om hannel ärrasödu 'dies ist durch die Gänse abgefressen'. Saksa keelele on selline possessiivi kasutusviis Boubrigi sõnul võõras ja seetõttu mõni eitab seda, kuid see on siiski üldlevinud, täpne ja õige eesti konstruktsioon;

4) koos 2. infinitiiviga, umbes samamoodi, nagu ladina keeles on accusativus cum infinitivo, nt külm ei anna wiljal kaswada (Boubrigi järgi on see Masingu väljend); lasse täl tetta 'laß ihn machen' (täll tähendaks Boubrigi sõnul 'für ihn'); ma kässi seppal kats rauda tetta 'ich befahl, daß der Schmied 2 Eisen mache'; sedda ei anta meil maitsagi 'wir bekommen davon nicht einmal zu schmecken'. Boubrig arvab, et just selliste väljendite tõttu on possessiivi ja daativit tahetud pidada üheks ja samaks käändeks. (B: $30 \mathrm{p}-31 \mathrm{p})$

Daativit kasutatakse Boubrigi sõnul

1) omaks andmise, pühendamise, loovutamise, eesmärgi seadmise, mingi koha või sihtmärgi poole liikumise väljendamiseks kitsamas ja laiemas tähenduses, nt kirrikule 'zur Kirche', kaasa arvatud seal viibimise eesmärk, muidu kasutataks ingressiivi [= sisseütlevat] „,in die Kirche“; põllule 'aufs Feld' (eesmärgiga tööle minna); põrgule jäma 'der Hölle verfallen, verbleiben' (sõnaga perris saaks väljendit veel tugevdada); hainale 'ins Heu'; rehhele 'zum Riegendreschen'. Masingu tekstidest ütleb Boubrig pärinevat väljendid auule üllendama 'ausse tõstma', surmale énnast valmistama, kaugele nähtud 'aus der Ferne gesehen' (lektor arutleb viimase väljendi üle ja imetleb selle täpsust: - lt või -st tähendanuks tema arvates, et peab ise kaugel olema). Rahvasuust üles märgitud on nt keddagi palwusele pannema 'kellelegi eestpalvet teha laskma'; pudsole löma 'pihuks ja põrmuks lööma' (sõnast pudso 'praht, prügi, pühkmed'); ajule sama 'õigeks ajaks tulema' jne;

2) kui püüeldav siht, asi või tegevus on väljendatud verbi 1. infinitiiviga, siis vastavasisuline noomen peab olema daativis, nt ussin teggema - ja töle, kärmas jooskma - ja jooskmisele, temma pä 
om rasse wõtma - ja wõtmiselle, ma nakkan teggema - ja töle. Boubrig hoiatab, et verbirektsioone ei tohiks lihtsalt empiiriliselt üles lugeda, nagu on teinud Hupel (vrd H: 129-135), vaid asjale peaks lähenema üldisemalt, filosoofiliselt, kuna kõiki verbe ja nende poolt nõutavaid käändeid üles lugeda ei jõua ja kuna käänded võivad olukorrast olenevalt olla erinevad, nt se om meile hä 'dies ist für uns gut', s.t endiselt hea, ja se olli meil hä õn 'das war uns etwas Gutes, fügte sich glücklich', s.t silmapilgul, mitte püsivalt;

3) mõnikord, kui kirjeldatakse seisundit, on daativ otsekui formatiivi [= saava käände] asemel, nt kui ta parrembale lät'wenn er besser wird' (vormi parrembas asemel), surembale minnema 'größer werden' jts. Siingi on Boubrigi arvates silmas peetud sihtmärki: 'zum Bessern', 'zum Größern'. Daativi kasutuse kohta on Boubrig lisanud veel mõne näite: wee warrale jäime otsani'zuletzt waren wir ganz auf Wasser gesetzt', kui viimane lehm suri ja enam tilkagi piima polnud; pikkale jäma 'sich in die Länge ziehen'; $t a$ on ikka omma issa nimmele 'tal on ikka veel sama nimi, kui oli tema isal', s.t isa talupere järgi, kuigi ta ise elab juba teises peres; üllem opmisele 'besser im Lernen'; lämmile wima 'warm stellen'. Lõppu on Boubrig lisanud, et „mõlemast daativist“" on juttu Beiträge 4. vihikus lk-del 122 ning 172 jj. (B: 31p-33) Viidatud kirjutised, mille seisukohad kajastuvad ka siinses loengutekstis, on Knüpfferi kaastöös leiduv märkus 1. ja 2. daativi kohta (Knüpffer 1815) ja anonüümse autori artikkel nende käänete kasutamisest (Ueber 1815).

\subsection{Egressiiv ja ablatiiv [ = seestütlev ja alaltütlev]}

Käänete kohta, mida varem nimetati ka 1. ja 2. ablatiiviks, annab Boubrig sellise põhireegli: egressiiv lõpuga -st väljendab vastet saksa tähendusele 'aus' ja ladina 'ex', seevastu ablatiiv (-lt) vastab saksa mõistele 'von' ja ladina 'de' või koguni 'de super', sest eesti ablatiiv märgib midagi pinnapealset, väljaspoolset, ülalt või väljastpoolt lähtuvat. Egressiiv aga, nagu osutab ta nimigi, väljendab rohkem midagi seestpoolt lähtuvat, mingit seesmist suhet. Loenguteksti servale on Boubrig samas (B: 33) lisanud viite Beiträge 12. vihikus leiduvale Petersoni artiklile. Noor keelemees 
seletab selles kahe ablatiivi kasutuserinevust ja süstematiseerib eesti kuus kohakäänet juba päris nüüdisaegsel kombel (Peterson 1818b).

Täpsustavalt märgib Boubrig, et egressiivi kasutatakse

1) sks 'aus' tähenduses, nt ihhust, tarrest, lummist, mạiast;

2) kui jutt on mingist osast, koostisosast või materjalist, nt anna mulle ossa sest rahhast; puust tettu;

3) kui midagi lähtub otseselt isikust või asjast, nt se om Jummalast antu; Jummalast lodu;

4) mõnes väljendis, kusjuures sageli on neis juurde mõeldav tähendus saksa vastega 'aus' või 'von', nt temmast kõnelti paljo; ka sks 'für' (ostmisel), nt ehteestiline mis sa saast küssit? 'was willst du für Hundert?'; või väljend ma lõisi sedda maast 'ich fand es auf der Erde', s.t maa andis selle. Boubrig ütleb, et ostetu hinna väljendamiseks kasutatakse heas eesti keeles ka unitiivi [= kaasaütlevat], nt Ma osti sedda rublaga. Taas on lektor üliõpilaste tähelepanu juhtinud teemakohasele kirjandusele: Masingu egressiivikäsitusele tema ortograafiabrošüüris (idamurde st-lõpulise saava käände mõjul oli Masing mõnd sellist vormi väitnud seestütlevaks, vt Masing 1824a: 36-37), Steingrüberi vastumärkustele (1826: 33) ning iseoma hilisemale loengutekstile (vt siin osad 16.9 ja 17.4). (B: 33p)

Täpsustavad reeglid ablatiivi kohta on Boubrigil sellised:

1) ablatiiv on otsekui possessiivi casus privativus, s.t lõpule - $l$ lisatakse privatiivne - $t$, et näidata millegi algset päritolu otsekui millegi muu küljest, nt Wennemaalt 'aus Rußland', sealt pärit; issandalt todi sõnna 'vom Herrn kam Befehl' (kui üldse oleks võimalik issandast, siis see tähendaks, et härra ise tõi käsu); tõbbitselt kuultas, ütteldas 'vom (über den) Kranken hört, sagt man'; küssi temmalt 'frage ihn', otsekui temalt ära; ma sain sedda temmalt (temmast tähendaks, et sain tüki temast endast); jummalalt pallema 'von Gott bitten', jummalat pallema 'beten' jne. Boubrig tsiteerib Petersoni näiteid: regivärsirida Tundi ta turrult tullewat ja näitele Tullin Wennemaalt järgnenud dialoogi isaga: Miks ma [ei] woi üttelda: Wennemaast? - Sest et Wennemaal ollid, agga mitte Wennelaste maas - ütles mo issa (vrd Peterson 1818b: 149);

2) ablatiivi kasutatakse, et peenemalt edasi anda saksa 'durch [kaudu, läbi]' vastet, nt köstrelt 'durch den Küster' (s.t köstri kaudu, nt saadetud), ma sadi jo kattelt sõnna 'ich habe schon durch Zwey 
Nachricht geschickt', Temma olli saatnu ommalt sullaselt 'er hatte durch seinen Knecht geschickt';

3) mõnest sõnast aga ei kasutata kunagi ablatiivi, vaid hoopis egressiivi, sest tõenäoliselt on ülekaalus tähendus, mille saksa vaste on 'aus', nt mõisast, mitte kunagi mõisalt; küllast, mitte kunagi küllalt; käest, mitte kunagi käelt. Boubrig lisab viite teemakohastele kirjutistele Beiträges, üks neist juba korduvalt viidatud artikkel Petersonilt (1818b), teine anonüümse autori kokkuvõte kahe ablatiivi [= seest- ja alaltütleva] tarvitamisest (Antwort 1826). Mõlema artikli seisukohad kajastuvad ka Boubrigi siinses käsitluses. (B: 33p-34)

\subsection{Ingressiiv [= sisseütlev]}

Seda käänet on Boubrigi sõnul korralikult kirjeldatud alles hiljuti. Teistest käänetest eristab seda teravam hääldus ja nõrkade kaksikkonsonantide muutumine tugevaks. Nii nagu ütleb juba nimi, kasutatakse ingressiivi eriti seal, kus näidatakse kuhugi tungimist, mingisse sihtpunkti minemist või üldse mistahes eesmärgistatud liikumist sihtpunkti. Boubrig ütleb, et just seepärast on seda käänet varem nimetatud ka accusativus directionis'eks või in locum'iks. Väga huvitav on Boubrigi arvates ka kasutusviis, kus püsivasse olekusse jõudmisel otsekui püüeldaks jäädagi sellesse olukorda, nt ta koli wette 'er starb ins Wasser hinein'; Wennemahe 'dem Rußland zu'; minno laps põlleb sisse. (B: 34p)

\subsection{Formatiiv $[=$ saav $]$}

Formatiivi (tln lõpuga $-k s$, trt $-s$ ) ei kasutata Boubrigi meelest mitte ainult selleks, et näidata, milleks miski saab või sobib, vaid ka nimetamisel või määratlemisel (seal, kus saksa keeles on sageli nominatiiv), nt tedda kutsutas Peetriks; ma arwan tedda sureks. Boubrig on teinud märkuse mitmuse moodustamise kohta: - $k s$ lisatakse mitmuses indefinitiivile, mis mitmuse sufikskäänetes tavaliselt astubki relatiivi asemele ning tuleb ära õppida. Kui indefinitiiv lõpeb konsonandiga, siis see jääb sufikskäände lõpu ees ära. Nüüd pöördub Boubrig tagasi Hupeli grammatika juurde, lisades viite leheküljele, kus on räägitud saava käände kasutamisest (Hupelil ,prepositsioon $-k s^{6 /}$; vrd H: 129-130). (B: 37; vrd ka siin punkt 17.4) 


\subsection{Relatiiv koos kaassõnadega versus sufikskäänded}

Boubrigi märkusest leheserval (B: 37) selgub veel, et ta kavatseb lisaks kõrvutada sufikskäändeid ja neile lähedasi väljendeid, kus relatiiv on koos sufikskäändele vastava kaassõnaga sees, sissen jts. Siinses tekstiosas ei ole Boubrig oma kavatsust realiseerinud ja ka Moritza loengukonspektis ei ole vastavat lõiku. (B: 37 jj; vrd Moritz: 53-53p) Käsikirja vahel leidub aga siinkohal Helleri sulest pärit lahtine leht, mis kannab daatumit 13. XI 1829 , s.t on kirjutatud juba pärast 1829. aasta kevadsemestri loenguid. Selle irdlehe on omaaegne arhivaar pagineerinud Boubrigi käsikirja juurde kuuluvana (B: 35-36p); käekirja põhjal saab seda Hellerile kuuluvaks pidada. Heller räägib siin muu hulgas sufiksite $-s(\ln )$ ja $-n$ (trt) vahekorrast kaassõnaga sees (tln), sissen (trt). Loodetavasti puudutas Boubrig seda teemat hilisematel õppeaastatel.

\section{Boubrigi kommentaarid Hupeli käändesüntaksi kohta}

Et tegemist on olulise teemaga, on Boubrig pidanud vajalikuks kriitiliselt üle vaadata Hupeli grammatikas käänete funktsioonide kohta öeldu. Kordamise vältimiseks esitatakse neid kommentaare valikuliselt.

\subsection{Nominatiiv, genitiiv ja akusatiiv objektikäänetena}

Nominatiivi kohta on Hupel öelnud, et eesti keel erineb mõnes osas teistest keeltest, sest mitmuse nominatiivi võib kasutada ka akusatiivi [= osastava] asemel, kui midagi määratakse ning jaatatakse, nt ta kutsub ommad lambad; ainsuses pole akusatiivi selline kasutamine võimalik (H: 126-127). Boubrig arvab sel puhul, et Hupel on selgelt väljendanud definitiivi akusatiivset kasutust määratud kõnes. Senise eesti kirjakeele vead ja sakslaste rikutud keelekasutus ei ole Hupelil lasknud õigeid järeldusi teha. Boubrig väidab, et ka ainsuses on võimalik definitiivi kasutada akusatiivselt, ning toob näite rahvasuust: Kohhes ma piim pannen? Ma küssin, kohhes ma piim pean pannema. Boubrigi arvates on ebaõige kirjakeel sellise kasutuse välja tõrjunud. Ta väidab ka, et vähemalt tartu keeles leiab mitmuses sageli indefinitiivi seal, kus peaks olema definitiiv. Boubrigi arvates võib põhjuseks olla soov vältida valestimõistmist seal, kus ainsuse relatiiv ja mitmuse definitiiv kõlavad ühesuguselt. (B: 37-37p) 
Boubrig ei kommenteeri Hupeli väidet, et eituste ja määramatuse korral kasutatakse alati akusatiivi, nt ei ta armasta lapsi; ta ostab hobbosid 'er kauft Pferde'. Kui aga Hupel kirjutab, et kehaosadest rääkides võib jaatavas kõnes kasutada kord nominatiivi, kord akusatiivi, nt ta pessis jallad või jalgo 'er wusch die Füße', siis ütleb Boubrig, et tähendused on erinevad, sõna vorm oleneb ikkagi definiitsusest-indefiniitsusest: definitiivi puhul oleks tähendus 'das Waschen der Füße' ja indefinitiivi puhul 'das Fußwaschen' (H: 127; B: 37p).

Käskiva kõneviisi objektist rääkides ütleb Hupel, et jaatavates lausetes kasutatakse nii ainsuses kui ka mitmuses enamasti nominatiivi, nt panne uks kinni; eitavates lausetes on aga alati akusatiiv, nt ärra panne ust kinni. Tartu dialektis kasutatakse ka jaatavates lausetes sageli akusatiivi. (H: 127) Boubrig kommenteerib: keelavates ja eitavates lausetes on objekt indefinitiivis, kuna ta otsekui kaob või muutub üldisemaks kõrvalseigaks. Jaatavas imperatiivis saab aga indefinitiivi kasutada olenevalt sellest, kuidas nõuab määramatu partitiivne või üldine tähendus. Niisiis ei ole käändevormide valikul oluline mitte imperatiiv, vaid kõne definiitsuse aste. (B: 37p-38)

Boubrig pole rahul ka Hupeli seletusega käänete kasutuse kohta passiivis: Hupeli järgi kasutatakse seal nominatiivi tallinna dialektis üksnes päris kindlate seikade puhul või ka veidi pikemates väljendites, nt innimesse poeg antakse ärra 'inimese poeg reedetakse'. Mõlemas dialektis aga kasutatakse samas ka akusatiivi vastupidi teistele keeltele. Hupeli arvates on tallinnakeelse piibli tõlkijad passiivis mõnikord nominatiiviga liialdanud. Vastavad kohad, millele Hupel osutab, aga mida ei tsiteeri, on nt minno tüttar waewatakse kurjast waimost või Se ep olle mitte hea, et laste leib woetakse ja koerte ette heidetakse (Mt 15: 22, 26, vrd Piibel 1739). Boubrig peab põhjendust ,pikemad väljendid“ lausa koomiliseks; Hupeli näidetes definitiivi kasutamise kohta on lektori meelest aga tegemist väga kindlate, määratud asjadega. (H: 127; B: 38-38p)

\subsection{Genitiiv täiendina, genitiivne ja nominatiivne liitumine, lisand}

Hupel ütleb, et genitiiv oleneb sageli teisest nimisõnast, näidates genitiivset suhet, ning on alati eesasendis, nt poia ainus laps, jummala arm. Selliselt seotud nimisõnad moodustavad sageli liitsõnu, nt jummala kartus, mida võib kirjutada ka jummalakartus. (H: 127-128) Boubrig väidab sel puhul, et tähendused on erinevad: kokkukirjutatu tähendus on 'Gottesfurcht', 
lahku kirjutatud fraas aga tähendab 'Gottes Furcht', s.t 'kartus, mida jumal tunneb'. Et Hupel on viidanud ka oma grammatika varasematele lehekülgedele, kus sellest õigekirjutusprobleemist juttu on, siis leidub Boubrigil mõni kommentaar ka nende kohta. (B: 38p)

Hupel räägib nimisõnalisest täiendist - vahel ka lisandist või ka liitnimisõna täiendsõnast -, mida ta nimetab apositsiooniks. Seal, kus saksa keeles on nominatiiv, on eesti keeles väga sageli genitiiv, nt talli poiss 'der Stall Knecht', merre weer (trt) või äär (tln) 'Meer-Ufer'. Tituleerimisel aga pannakse saksa väljendis teisena olev sõna eesasendisse genitiivi, nt kenrali-herra 'der Herr General', toktri praua 'die Frau Doktorin'. Ka kohanimede puhul esineb Hupeli sõnul midagi sellesarnast, nt Mäemoisa saksad 'die Herrschaft von Berghof'. Põhisõnaga samas käändes esineb apositsioon nt väljendis issand jummal 'Herr Gott' ja paljudes ühendites, kus esimene sõna näitab teise materjali või kasutust, nt laud linna 'Tischtuch', wask riist 'Kupfer- oder kupfernes Geräthe', king-sep 'der Schuster'. (H: 128-129) Boubrigi jaoks on mõiste olnud kitsama sisuga: ta näeb apositsiooni üksnes väljendis issand jummal (apositsiooni kasutavat eestlane harva), kõik ülejäänud Hupeli näited on tema arvates lihtsalt nimisõnaühendid. (B: 39p)

\subsection{Kui kaua? Kelle sarnane? Mida väärt?}

Küsimusele „wie lange?“' 'kui kaua?' saab Hupeli arvates vastata nii genitiivi abil, nt ta seisis seäl ühhe aasta 'er hielt sich dort ein Jahr auf', kui ka (ühest suuremate arvude puhul) nii, et arvsõna on nominatiivis ja nimisõna akusatiivis, nt ta seisis seäl kolm aastat 'er hielt sich dort drey Jahre auf'. (H: 128) Boubrig kommenteerib seda jälle definiitsusestindefiniitsusest lähtudes: esimesel juhul mõlgub kõneleja meeles midagi määratut, mida kuulaja aga ei tunne - seetõttu relatiiv; teisel juhul aga on tähtis aastate arv, seda väljendatakse definitiivis, millega liitub nimisõna indefinitiiv. (B: 38p-39)

Hupel ütleb, et võrdlust sisaldavad adjektiivid nõuavad genitiivi, nt minno suggune, tulle wäärt, sinno sarnane. (H: 128) Boubrig peab öeldut muidu õigeks, aga lisab näidete hulka veel omadussõna arwolinne, nt ta on temma arwolinne; veel parem oleks tema arvates öelda ta om temmaga arwolinne. Sõna wäärt nõuab Boubrigi meelest tavaliselt pigem indefinitiivi: temma on sedda wäärt, et jne, mitte selle, sest see, mida temma 
väärt on, vajab järgnevas alles täpsustamist. Lektor soovitab vaadata ka Hupeli grammatika lehekülge 133, kus leidub väide, et pronoomenid on sõna wäärt ees enamasti akusatiivis. (B: 39)

\subsection{Verbirektsioonid}

Edasi räägib Hupel verbide putuma, puutma, hakkama, surrema rektsioonist. Et sisseütlevat tema grammatikas käändenimetusena veel ei ole, siis ütleb ta, et saksa tähenduse 'an' väljendamiseks lisatakse neile verbidele noomeni genitiiv koos silbiga -sse, nt putuma naesesse või luusse 'ein Weib oder ein Bein anrühren', hakka temmasse kinni 'fasse ihn an', ta surri rinna tõbesse 'er starb an der Brustkrankheit'. Mitmuses kasutatakse tema sõnul alati akusatiivi, nt ärra putu mo jalgo 'rühre meine Füße nicht'. Lisaks on veel võimalikud väljendid, nagu ta hakkas temmast kinni' 'er griff oder faßte ihn an', ta hakkas temma kätte kinni 'er hielt ihm die Hände', ärge putuge rojase külje 'rührt kein Unreines an'. Kui putuma tähendab 'angehen' või 'betreffen', siis on rektsiooniks akusatiiv, nt se ei putu mind 'das geht mich nichts an'. (H: 129) Boubrig ütleb kõigepealt, et Hupeli genitiiv + -sse on muidugi casus ingressivus. Siis pahandab ta, et Hupel pole lahus hoidnud transitiivseid ja intransitiivseid verbe, mida eestlased alati väga täpselt eristavad. Ka rektsioonide kirjeldus ei rahulda Boubrigit ning ta esitab oma tõlgenduse:

1) putma 'berühren, anrühren' on transitiivne verb, mille rektsiooniks on olenevalt olukorrast kolm pea- ehk relatsioonikäänet, nt ärra putko mo jalgu 'rühre meine Füße nicht';

2) puttuma 'berühren, anrühren, ankommen, sich anhängen, sich an etwas machen, betreffen, angehen' on intransitiivne verb, mille rektsiooniks on a) ingressiiv, eriti kui jutt on täpsest või otsekui sisse tungivast puudutusest; b) daativ, enamasti dativus commodi [lad, daativ, mis näitab, kelle või mille kasuks midagi tehakse], mis käib isiku kohta, nt ta ei puttu middagi táha (demonstratiivpronoomenist ta) 'see ei puutu üldse siia'; se ei puttu sia; päiw puttub silmi või silmile; hoija, et klasi külge (või külgede) ei puttu 'hüte dich, daß du das Glas nicht anstoßest'; päiw puttup päle 'die Sonne scheint (Euch) darauf'; latse, kes nakkase kässile puttuma 'lapsed, kes juba hakkavad (oma vanemate) käekõrval kõndima'; 
3) hakkama või nakkama ja surrema juurde kuuluvad ka koolma (trt) ja jäma 'dauernd wohin gerathen'; nende verbide rektsiooniks on ingressiiv, nt jäma wette 'im Wasser umkommen [uppuma]', ta koli tõppe 'er starb an dieser Krankheit'. Boubrig märgib veel, et ka tartu dialektis leidub väljend ta nakkas temmast kinni. (B: $39 p-40 p)$

Translatiivi Hupeli grammatikas samuti veel käändenimetusena ei esine. Seetõttu kirjeldab Hupel seda vormi nõudvate verbide rektsiooni kui genitiivi, millele tuleb lisada $-k s(\mathrm{t} l n)$ või $-s$ (ehk mõne arvates $-s s$, trt). Ta ütleb, et sellised verbid väljendavad tegemist, saamist-muutumist, nimetamist, hindamist, arenemist, kestmist, jäämist, manitsemist, vahel ka olemist, omamist ja midagi tulevikulist: ta jäi sandiks, ta teggi ennast haigeks, ta on seäl karjatseks, se tulleb teile heaks; trt jäge terwes, puhtas sama, jummala auwus. Mitmuse vormides tuleb -ks lisada akusatiivile, jättes sealt ära võimaliku -t, nt ta on neid seädnud õppetajaiks. Sõnad paar, tük, nattuke saavad samasuguse lõpu kui nimisõna, mille juurde nad kuuluvad, nt jä pariks päiwiks, tulle nattukesseks ajaks. (H: 129-130) Boubrigi sõnul on tegemist casus formativus'ega [= saava käändega]. Käändelõpu kohta ütleb ta, viidates Hupeli grammatika morfoloogiapeatükile, et kujul $-s$ ei esine sufiks mitte ainult tartu, vaid ka tallinna keele alal, nimelt Pärnumaal (kuhu tollal kuulus ka Mulgi murde ala); Virumaal ja Peipsi ääres on see aga -st, kusjuures mitte ainult Peipsi murde alal kuni Emajõeni, nagu on märkinud Hupel (H: 116), vaid ka tartu keele piirkonnas Räpina, Võnnu, Põlva ja Vastseliina kihelkonnas. Veel kord meenutab Boubrig, et Masingu seisukoht, nagu oleks siin tegemist egressiivi [= seestütleva] lõpuga, ei pea paika. (B: 40p-41; vrd siin punkt 16.7 ja Masing 1824a: 36-37)

\subsection{Kaks daativi ehk Veel kord alaleütlev ja alalütlev}

Daativit nimetab Hupel käändeks, mis näitab teatud suunda, nt anna mulle. 1. daativ näitab liikumist mingile kohale, vastab küsimustele „wohin?“ 'kuhu?' ja „wozu?“' 'mistarvis?'; võib väljendada ka tähendust, mis on saksa prepositsioonidel in, auf, an, zu, gegen koos akusatiivi või ablatiiviga; nt wihhale kihhotama 'zum Zorne reißen', ta läks kirrikule 'er ging in die Kirche', ma lähhän põllule 'ich gehe aufs Feld', ennast seädma taplusele 'sich zum Streite anschicken', nodale minnema 'fischen gehen', sõna-sõnalt 'zum Netze gehen' jts. (H: 130) Boubrig märgib sel puhul, et 
on nende käänete (daativi ja possessiivi) kasutamist juba varem analüüsinud (vrd punkt 16.6). Ta lisab oma varasemale käsitlusele veel mõtte, et possessiivi lõpule $-l$ daativis lisatav $-e$ näitab otsekui liikumist ühelt kohalt teisele, nii et seda võiks nimetada e protractivum'iks. Väljendit kirrikule minema (vrd Hupeli vastav näide) kasutatakse Boubrigi sõnul sageli tähenduses 'armulauale minema', seevastu kirko (või kirrikohe) minnema tähendab 'kirikus käima'. Samamoodi on ka ma lähhän põllule 'lähen põllule tööle' ja ma lähhän põldo (kaema, watama) 'lähen põldu vaatama'. (B: 41-41p)

2. daativi kasutusvõimalusi on Hupel esitanud viis: 1) tähenduses 'haben' koos verbiga ollema, nt mul on wiis wenda; 2) tähenduses 'schuldig seyn', nt mul on temmaga wõlgo 'ich bin ihm schuldig'; 3) koos impersonaalse verbiga täib, nt mul ei täi ennam anda 'ich kann nicht mehr geben; 4) adverbina, nt sõnadest kabbin või mürrin saadud väljendid kabbinal või mürrinal; 5) aega, kohta või viisi osutades, nt neil päiwil, sel kombel või sel wisil, nimmel, tln parremal ning pahhemal käel, trt hääl nink kurral käel jts. (H: 130)

Boubrig mainib kõigepealt, et Hupeli 2. daativ on tegelikult possessiiv. Seejärel imestab ta, et Hupel on pidanud vajalikuks ühe verbi ja ühe väljendi esitada eri kasutusjuhtudena (punktid 2 ja 3). Teise punkti väljendil on Boubrigi arvates veel üks tähendus: 'me oleme võla kaudu seotud, peame omavahel arved õiendama'. Ta juhib üliõpilaste tähelepanu Helleri Beiträge artikli ,väga õpetlikule lõigule“ sõnade wõlg, wõlga ja wõlgo kohta (vrd Heller 1822a: 102-104, kust on pärit Boubrigi siin lisatud tõlgendus). Boubrigile ei meeldi possessiivivormi käsitamine adverbina punktis 4, pealegi saab tema arvates sellist vormi kasutada vaid koos verbiga ollema, seega kuulub see näide punkti 1 alla. Ka viies kasutusjuhtum polevat Hupelil õigupoolest muud kui omamist, kuulumist näitav. 1. punkti täienduseks ütleb lektor veel, et vahel pole verbi ollema vaste saksa 'haben', nt mehhel ollema 'verheiratet seyn'; tarro (ka tarro pu, tarro pak) om häste osel 'der Bienenstock ist gut ausgehöhlt [tarupakk on hästi õõnestatud]'; emma jo olli nurgawodil 'die Mutter lag schon in den Wochen'; pärral ollema 'schon dort seyn'; jallul ollema 'auf den Beinen seyn'. (B: 41p-42) 


\subsection{Hupeli akusatiiv Boubrigi silme läbi}

Akusatiivi kasutamist on Hupel kirjeldanud ühtekokku neljateistkümnes alapunktis (H: 130-134). Ta ütleb, et akusatiivi nõuavad tavaliselt aktiivverbid ning eriti eitavates väljendites, kuna jaatavas kõnes võib akusatiivi asemel mõnikord olla ka ainsuse genitiiv või mitmuse nominatiiv. Kuid akusatiivi võib kasutada ka mujal: 1) tallinna dialektis sageli passiivis, nt neid ristiti 'sie wurden getauft'; tedda widi ärra 'er ward weggeführt'. Tartu dialektis on Hupeli sõnul sel juhul sageli nominatiiv; 2) sõnadega, mis näitavad hulka, suurust, mõõtu jms, nt paljo innimessi, hulk lambo, pissut weiksid 'wenig Vieh', üks wak kaero, üks kümmekond mehhi 'ein Stücker zehen Männer', täüs wina, neid mehhi om kül 'der Leute giebt es genug'; samamoodi ka kan ôllut, koorm puid; sõna mitto 'wie viel' nõuab ainsuse akusatiivi: mitto innimest 'wie viele Menschen'; 3) koos põhiarvsõnadega, mis on nominatiivis või akusatiivis, nt kolm meest, wiis koorma; 4) komparatiivi järel, nt tln surem mind, trt suremb minno 'größer als ich'. Mõnikord aga kasutatakse ka ablatiivi [= seestütlevat], eriti pikemates väljendites, nt ta on kaks aastat norem minnust; ka superlatiivses tähenduses, nt trt tä om illo polest kige lähhämb temmäst'er kommt ihm in der Schönheit am nächsten'. Selguse pärast kasutatakse vahel ka sõna kui, nt hobbosed on suremad kui koerad. (H: 130-131)

Boubrig esitab esimese punkti juurde lisaks rahvasuust pärit näiteid, kus passiivis on definitiiv tema sõnul lausa kohustuslik, sest tegu on juba varem kõneks olnud ja piisavalt määratud asja või isikuga: kõik mis temma õppettedas 'alles, was man ihn lehrt', kus temma on rõhulises, määratud vormis; üts anti soldanist ärra 'üks (määratud) anti soldatiks' jts. Teise punkti kommentaariks ütleb ta, et mitto nõuab küll ainsust, paljo mitmust, kuid mõnikord mitmus lihtsalt ei sobi, nt paljo teggemist, paljo liwa, paljo rahwast. Neljanda punkti juures väidab Boubrig, viidates oma varasemale komparatiivikäsitlusele (vt siin punkt 16.4), et ta om minnust suremb tähendab 'er ist größer, als ich' ja ta om suremb minno rõhk on 'er ist größer, als ich'. (B: 42)

Hupeli järgi kasutatakse akusatiivi 5) koos mitme sellise verbiga, mis saksa keeles nõuavad daativit: aitma, käskma, keelma, ülles-passima 'aufwarten [teenima, passima, ümmardama]', tenima, kuulma 'gehorchen [sõna kuulama, kuuletuma]', uskma, tännama (trt, tln), tennama (tln) jts, nt kela tedda; teni mind; minna ei ussu neid; kuid siiski jummala sisse 
uskma 'an Gott glauben'. Verb öppetama (tln), oppetama (trt) aga nõuab akusatiivi nii eesti kui ka saksa keeles; ainult vahel võib kohata daativit, nt trt oppeta mulle sinno kohhut 'lehre mich deine Rechte'. (H: 131-132) Boubrig väidab, et õppetama võib olenevalt olukorrast esineda nii koos indefinitiiviga kui ka definitiiviga; koos daativiga esinemist peab ta aga ebaõigeks, kuna selle verbi tähendus on 'lernen machen [õppima panema]', mis nõuab otserektsiooni [= sihitist]; seega: õppeta neid või nemma sedda. (B: 42p)

Järgmises kahes punktis on Hupel akusatiivina käsitanud osastava kõrval ka sisseütlevat, mida tema grammatikas veel käändenimetusena ei eksisteerinud. Ta ütleb, et akusatiivi kasutatakse 6) koos verbidega, mis väljendavad liikumist mingisse kohta, kusjuures jäävad ära saksa keeles esinevad prepositsioonid, nt wangi minnema, hauda pannema, trt istu tohhe paika 'setze dich an diesen Ort'. Märkused, mis ta sel puhul teeb, kõlbaksid illatiivi vormimoodustusreegliteks. Ta märgib ka, et genitiivile lisatava lõpu -sse asemel võib olla kaassõna sisse.

Samasugust osalt teisendatud akusatiivi näeb Hupel 7) koos verbidega, mis väljendavad jäämist, viibimist ja otsimist, nt ma ollen seäl asset ('ma elan seal'; siin küll ka nüüdispilgu jaoks partitiiv); ta jäi senna, mitte seäl, nagu oleks saksa vastes 'er blieb dort'; otsi senna tuppa, mitte seäl toas, vrd saksa vaste 'suche dort in der Stube'. (H: 132) Boubrigi kommentaar on muidugi, et tegu on ingressiiviga. Ta toob mõne lisanäite paralleelvormide kohta (paika ehk paikahe jts), korrigeerib mõnd näidet (súho, samuti ka máha, sest lõppvokaal on tavaliselt samasugune kui eelmises silbis) ning püüab seletada mõne vormi kujunemist, nt tuulde < tuulthe, kätte < käthe. Ta oletab (näidet lisamata), et -he lisamine kord relatiivsele, kord indefinitiivsele tüvele on seotud sellega, missugune on kõne määratuse aste. Veel märgib Boubrig, et tartu dialektis ei kasutata verbidega otsma, kaema jts mitte ingressiivi, vaid egressiivi, nt otsi säält tarrest, kae säält kambrest. Sellise indefinitiivi näitena, kus saksa keelega võrreldes ei kasutata prepositsioone, esitab ta adverbiaalsed väljendid sedda wiisi ja sedda wärki. (B: 42p-43)

Hupeli järgi kasutatakse akusatiivi 8) koos verbidega, mis väljendavad haigust, kusjuures saksa keeles esinev kaassõna jääb taas ära, nt ta põeb jalgo 'er kränkelt an den Füßen', ta kaebab pead 'er klagt über den Kopf', trt põddema wauwa või kõtto tõppe (H: 132). Boubrig esitab sel puhul teise tartukeelse kuju wauh 'äge palavik' koos väljendiga wauhha 
põddema. Indefinitiivi kasutamist koos verbiga põddema seletab Boubrig sellega, et tegemist olevat indefiniitse üldmõistega, nt jalgo põddema 'fußkrank seyn'. (B: 43)

Hupel ütleb, et akusatiivi kasutatakse 9) koos isikulises tegumoes olevate verbidega impersonaalsetes lausetes, s.t seal, kus saksa keeles on „es“, nt jubba tulleb rahwast'es kommen schon Leute', siit käib tuult 'hier wehet Wind', sa-ab või saddab wihma 'es regnet'; verbi ollema puhul oleks vastav tõlge ka 'es giebt', nt siin on monda teggemist 'hier ist ..' või 'hier giebt es allerley Arbeit'. Samas märgib Hupel, et vastupidi teistele keeltele kasutatakse eesti keeles akusatiivi koos verbi ollema eitavate vormidega, seda isegi siis, kui jaatavas vormis on nominatiiv, nt tln, trt neil ei olle wina 'sie haben keinen Wein' või trt otsa ei olle weel kä 'das Ende ist noch nicht vorhanden'. Jaatavas vormis võib akusatiiv olla määramatuse korral, nt tln mul on willetsust 'ich habe Unglück', trt neil om leibä 'sie haben Brod'. Isegi määratud kõnes võib mõnikord olla akusatiiv, nt trt kummal om ilmkoolmist 'der die Unsterblichkeit hat [kellel on surematus]' (1Tm 6: 16). Hupeli arvates poleks ka nominatiiv sellistel puhkudel kuigi suur viga. (H: 132-133) Boubrig kordab kommentaaris oma põhipostulaati: verba impersonalia korral on määramatus kõnes indefinitiiv, poolmääratud kõnes relatiiv ja määratud kõnes definitiiv. 1827. aasta tartueesti kalendris on saddap wihm täitsa vale, õige oleks wihma, sest kõnes pole ju täpselt määratud vihm. Väljendis suur teggeminne om temmaga on täpsustajaks adjektiiv suur; Boubrigi arvates ei tohiks sel juhul indefinitiivi kasutada, nagu ka nt se ei massa kirjotaminne 'das ist des Schreibens nicht werth' (s.t parajasjagu kõnes olnud, määratud kirjutamine) või tuul käüb siit 'der Wind kommt von der Seite'. Piiblikoha tõlge on Boubrigi väitel igatahes vale ja kummaline; kui ehtsas eesti keeles oleks olemas mõistet 'Unsterblichkeit' tähistav sõna, siis peaks see siin olema definitiivis. Ta pakub tõlget ke iggawel surma ei näe. Hupeli viimast märkust peab Boubrig lausa koomiliseks, sest ainsa õige lahenduse kohta on väidetud, et see poleks suur viga. Hupeli ühes näites esinevat vormi kä tõlgendab Boubrig lühenenud inklusiivina [= seesütlevana], trt käeh, tln käes. (B: 43-44)

Hupeli sõnul tuleb akusatiivi kasutada 10) koos verbiga räkima, kusjuures võimalik on ka ablatiiv, nt kedda või kellest sa räkid; verbi kartma rektsiooniks on nagu saksa keeleski kas akusatiiv või väljend koos kaassõnaga, nt ma kardan tedda 'ich fürchte ihn' ja ma kardan temma eest 'ich fürchte mich vor ihm'. Verbide käima (tln), kä̈̈ma (trt) akusatiivirektsiooni 
kasutamisel vanuse osutamiseks jääb ära saksa keeles olev kaassõna, nt ta käib kolmat aastat 'er geht ins dritte Jahr'. (H: 133) Boubrig on verbi räkima kommentaarina esitanud teise samatähendusliku verbi, nimelt kõnnelema. Oma näite keddas sa kõnnelet? seletamisel keskendub Boubrig interrogatiivsele sufiksile $-s$, mis tema meelest on pärit küsipartiklist es ja mida ta näeb nt sõnades kas, mis, kes, kuis, ons. Ta räägib ka partiklitest -ep ja -ap, nt seepse 'see ep see', küllap, sealap, ning peab kirjakeele jaoks liialt labaseks lühendusi, nagu tln ons, polnd või trt seepse, topsom 'too ep see om'. Ta viitab ka vastavatele lõikudele Masingu raamatus „Ehstnische Originalblätter“" ja ajakirja Beiträge 12. vihikus (lk 30; vrd Masing 1816a: 52; Knüpffer 1818b: 30). Hupeli näidet ma kardan temma eest peab Boubrig puhtaks germanismiks, sest ehteestilised kartma ja pelgama nõuavad tema sõnul otseobjekti [= sihitist]. (B: 44-45)

Järgmine akusatiivi kasutusjuht on Hupelil 11) koos sõnadega tarwis, tln waia, trt waja, waja ollema, wäärt, nt trt temmäl om teid waja 'er bedarf euer'. Saksa keele genitiivi asemel on eesti keeles koos sõnaga wäärt akusatiiv, nt ei ta olle sedda wäärt' 'er ist dessen nicht werth'. Kaassõnana on pool koos genitiiviga, kuid tartu dialektis võib ta nimisõnana tähenduses 'Seite, Gegend' esineda ka koos akusatiiviga, nt ne kumma wäljal pool meije maad omma 'diejenigen welche außerhalb unseres Landes sind'. (H: 133) Boubrig seletab siin kõigepealt väljendite waja ollema ja tarwis ollema tol ajal eksisteerinud tähenduserinevust: esimene neist tähendab 'abiks või täienduseks hädavajalik olema', seega ka 'puuduma', 'mitte käepärast olema'; teine aga 'zu statten kommen [marjaks ära kuluma]', sedavõrd ka 'tarvilik olema'. Nt mul om sedda waja 'ich habe das nöthig, bedarf dessen; mul om sedda tarwis 'ich kann das gebrauchen'. Boubrig väidab koguni, et saab küll öelda tarwis minnema, aga mitte waja minnema. Sõna wäärt kohta ütleb ta, et see on küll saksa laen, aga eesti keeles hästi kodunenud; sellega koos olevad demonstratiivpronoomenid on indefinitiivis, nt sedda, taad, seddasama jms wäärt, millele peaks veel järgnema või vähemalt juurde mõeldav olema et või mis. See, millega võrreldakse, on relatiivis, nt ta om kohto, karristuse wäärt. Sõnad wäljalpool 'außerhalb', sisselpool 'innerhalb', tolpool 'jenseits', selpool 'diesseits' on Boubrigi meelest liitsed kaassõnad, mida tuleb kasutada indefinitiivis oleva substantiivi ees; verbiga koos esinedes on tegu adverbidega. (B: 45-45p)

Akusatiivi (või vahel ka genitiivi) kasutatakse Hupeli sõnul 12) seal, kus ladina keeles on accusativus cum infinitivo, nimelt $w$-partitsiibis, 
mis esineb koos tundeid, arvamust, otsustust, teatamist, tunnetamist jms väljendavate verbidega, nt tln nemmad mõtlesid ennast waimo näggewad, trt nemmä mõtliwa hendä waimo näggewät 'sie meinten sie sähen einen Geist'; trt temmä näggi teddä maan ollewat 'er sahe daß er an der Erde lag'. (H: 134) Boubrig arvab sel puhul, et Hupel on seda teemat käsitlenud liiga vara, tegelikult tuleks sellest rääkida alles leheküljel 139, s.t partitsiipide juures. (B: 45p)

Hupeli järgmist lõiku tõlgendades tuleb meeles pidada, et tema grammatikas ei olnud kõigil nüüdiskäänetel veel käändenimetusi ning et käände- ja tuletussufikseid ei eristatud veel päris täpselt. Hupel väidab nimelt, et akusatiivi kasutatakse 13) koos prepositsioonidega, mis on oma substantiivi ees, nt trt een ilma pohjandamist 'vor Grundlegung der Welt [enne maailma rajamist]', pärrast mind 'nach mir'; aga ka koos mitmuslike vormide lõppu lisatavate tähtedega $s, k s, l i, t i, t a$, nt põlwili 'auf die Knie' ja ilma lapsita 'ohne Kinder'. (H: 134) Boubrigi tõlgendus on siin praegusajale lähemal. Ta tuletab kuulajatele oma morfoloogiakursusest meelde, et sufiksid $-s(\operatorname{trt}-n),-k s($ trt $-s)$ ja -ta tähistavad käändeid, -li on adverbisufiks, - $t i$ (ja ka -to) moodustavad adjektiive, nt põlwili' kniewärts, knieliegs', wäeti 'kraftlos'. Vormiõpetuse kohta käib ka kommentaari see osa, kus Boubrig seletab mitmuse käänete moodustamist põhiliselt mitmuse indefinitiivi alusel; mitmuse relatiivi kasutavat eestlane mitmuse käänete moodustamisel üksnes heakõla pärast või soovist end definiitsemalt väljendada. Boubrig arvab, et paljud kirjamehed ja ka vanemad grammatikad eksivad siin tegeliku keelekasutuse vastu, püüdes ka mitmuse käändeid moodustada ainsuse analoogial, s.t põhiliselt relatiivi põhjal. (B: 45p-46p)

Akusatiivikäsitluse lõpuks mainib Hupel selle käände tarvitamist 14) koos hüüdsõnadega oh, o!, ennä, nt trt oh süwwiust 'oh sügavust!', ennä innimest 'vaata (või vaadake), milline inimene'; koos sõnaga nätse 'vaata!' kasutatakse Hupeli arvates aga sageli nominatiivi (H: 134). Oma kommentaaris peab Boubrig definitiivi kasutamist viimasel puhul ebaõigeks, põhjendades seda etümoloogiaga näet sa või näet se. Boubrig väidab, et indefinitiivi kasutatakse hüüdsõnade järel seetõttu, et hüütav on esialgu määramatu, muutudes kõneaineks alles pärast hüüatust. (B: 146p) 


\subsection{Ablatiiv ehk Veel kord seestütlev ja alaltütlev}

Hupel ütleb, et eestlane pruugib ablatiivi lõppe -st ja -lt läbisegi, kuid näib, et teatud väljendis kasutab ta kindlalt vaid üht neist. Mõned ütlevad, et -st vastab saksa tähendustele 'aus' ja 'von' ning - lt vaid tähendusele 'von'. Teised taas arvavad, et lõpu -st abil väljendatakse alistumist, lõpu -lt abil aga tegemist. Täpseid reegleid on Hupeli meelest raske anda, kuid silmas võiks pidada järgmist:

1) esimest ablatiivi kasutatakse adjektiivide tühhi, haige, wagga, ilma-süta, rikkas, wiggane, lahti, woimato, ossalik'osaline', raske jts järel, samuti ka väljenditega pudus või ilma ollema; saksakeelne vaste on enamasti prepositsioon ,an“, nt tühhi rahhast 'leer am oder vom Gelde', haige jallast 'krank am Fuße', minna ollen ilmasüta sest werrest 'ich bin unschuldig an diesem Blute', th nemmad on jummala au-ust ilma, trt neil om pudus jummala kittussest 'sie mangeln des Ruhms an Gott' (Rm 3: 23);

2) st-lõppu kasutatakse ka koos verbidega leidma (tln), löidma (trt) ja otsima; vastavad saksa prepositsioonid võivad olla „,in“, ,auf“ või „bey“, nt ma leidsin maast 'ich fand es auf der Erde' (sõna-sõnalt 'von der Erde'); ablatiivikujulised on ka küsimusele „woher?“ vastavad adverbid ja kaassõnad, nt ma leidsin laua peält (mitte peäle) 'ich fand es auf dem Tische' (sõna-sõnalt 'von dem Tische');

3) esimest ablatiivi kasutatakse koos verbidega kiitlema (tln), kitlema (trt) 'sich rühmen', kiitma (tln) ja kitma (trt) 'rühmen', nii tln kui ka trt häbbenema ja häbbendama 'sich schämen', mõnikord ka koos verbiga minnema; nt tln ta kiitleb sest 'er rühmt sich dessen', trt ärra kitko rikkas ommast rikkussest 'der Reiche rühme sich nicht seines Reichthums', tln mis ma sest holin, trt mes minna sest holi 'was frage ich darnach', häbbene temmast 'schäme sich dessen', ta läks uksest wälja 'er ging zur Thür hinaus';

4) teist ablatiivi kasutatakse tavaliselt koos verbidega küssima ja küssitellema, wötma, sama, palluma, laenama, kulama, noudma jne, nt küssi temmalt 'frage ihn' (või 'von ihm'), temmä nous neilt 'er forschte von ihnen', tln ta pallus temmalt sedda 'er bat ihn darum' (või 'er bat es von ihm'); kuid siiski tln jummalat palluma 'Gott bitten'. (H: 134-135)

Kommentaariks on Boubrig kõigepealt viidanud oma siinsele ablatiivija egressiivikäsitlusele (vt siin punkt 16.7) ning soovitanud õige kaasuse 
valikul lähtuda vastava käände põhitähendusest. Egressiivi nõudvate verbide hulka (vrd Hupeli punkt 3) lisab ta veel tegusõnad tagganema, (ennast) rõmustama ja pahhandama. Boubrigi siinkohal viidatud allikaks on ajakirjas Beiträge ilmunud anonüümne artikkel märkustega Hupeli grammatika kohta. Muu hulgas puudutatakse selles kirjutises põgusalt ka kahe ablatiivi küsimust; mõni Boubrigi siinne näidegi on pärit just sealt. (Vrd Anmerkungen 1821: 44) Boubrig ütleb nimelt, et ka näidetest peaks olema abi, et selgitada tähenduserinevust, nt minna tean kõik mis temmalt on rägitud ja temmast on rägitud; minna sain temmast kuulda ja temmalt kuulda. Boubrigi tähendusseletused on praeguse kirjakeele vastavate rektsioonidega vastuolus: temmast kuulda 'kuulda, mida ta ise ütles' ja temmalt kuulda 'kuulda, mida teised tema kohta ütlesid'; tõbbitselt kuultas 'über den Kranken hört man [haige kohta kuuldakse või haigest kuuldakse]'. Arvatavasti on siin lõunaeestiline ja põhjaeestiline keelepruuk olnud erinev ja kõikuv: Boubrigi tekstis on parandusi ja küsimärke ning lõpuks nendib ta otsesõnu, et asi vajab veel täpsemat uurimist. Siiski meenutab Boubrig veel kord, et Masingu näites minna tullen lõunesömajast teile ei ole -st mitte egressiivilõpp, vaid murdeline formatiivi [= saava käände] lõpp (vrd siin punktid 16.7 ja 17.4). Ta lisab, et formatiivi asemel oleks selles näites ehk kohasem daativ, mida ju on nimetatud ka lokatiiviks: minna tullen sömajale, kas teile või teie mannu. Boubrig osutab raamatule, kust viimane soovitus pärineb (vrd Steingrüber 1826: 33), ning loodab, et ka Masingu hiljuti ilmunud selgitustest võiks kasu olla (vrd Masing 1827). (B: 46p-47)

\section{Infiniitvormide süntaks}

Hupeli grammatika süntaksiosa kolmas peatükk räägib infinitiivide ja gerundiumide [= verbi käändeliste vormide] kasutamisest (H: 135-139). Sageli autor lihtsalt loetleb verbe ja adjektiive, mis nõuavad teatud verbivormi, kusjuures loetelud pole mõistagi ammendavad, lõppedes ikka mingi jne- või jts-tüüpi lühendiga. Vahel on Hupel püüdnud lisada ka üldistavama iseloomustuse. Nii ütleb ta näiteks, et 1. [ma-] infinitiivi kasutatakse verbide järel, mis märgivad liikumist mingisse kohta, kuid tema loendis olevate tegusõnade tähendusskaala on laiem: aiama, awwatellema, hakkama, jäma, kõlbama, minnema, õppima, pannema, peäsma, piddama 'sollen', ruttama, saatma 'schaffen', sundima, teggema, tullema, heitma 
(maggama), uinuma (maggama); th rahwas istus mahha söma ja joma ja tousis ülles mängima, trt rahwas iste mahha söma nink joma nink tössi ülles mängmä. Ka verb õppetama nõuab Hupeli sõnul mõnikord 1. infinitiivi. Samas tullema tähenduses 'seyn [olema]' või 'gebühren [pälvima]' liidab endaga 2. [da-] infinitiivi, nt nüüd tulleb tähhele panna 'nun ist zu bemerken' või temmal tulleb au anda 'ihm gebührt Ehre'. 1. infinitiivi nõudvate adjektiividena on Hupel esitanud sõnad ussin, walmis, kindel, ablas, äkkine, wäggew, täis, auwus 'würdig', sagge; wäggew üllesehhitama 'mächtig zu erbauen', sagge käima 'der oft hin und her geht'. (H: 136) Samamoodi on ta vaadelnud ka 2. infinitiivi ning mata-, mas-, des-, nud-, tud-, v-, vat- ja mine-vormide süntaksiprobleeme.

Selline käsitlusviis Boubrigit igatahes ei rahulda. Ta soovib ka seda teemat käsitleda üldistavamalt, ,,filosoofilisemas vaimus“", mitte üksikuid verbe või adjektiive üles lugedes, sest sellised loendid on ebakindlad ega suuda olla ammendavad, seda enam et eesti keele sõnavaragi pole veel hõlmavalt kirjeldatud. Juba esimestest Hupeli reeglitest, mis käsitlevad 1. infinitiivi nõudvaid verbe ja adjektiive, puudub Boubrigi meelest hulk sõnu, nt ollema, süütma, jätma, kihhotama 'anreizen', kiusama, eksitama; nobbe, pitkaline, wahwas 'stark, kräftig', holas, kõlbaw, kõlbato, julge, kerme. Verbi õppetama järel on Boubrigi sõnul alati 1. infinitiiv (mitte „mõnikord“, nagu ütlevat Hupel). Lektor viitab ajakirja Beiträge vihikutele ja lehekülgedele, kus seda teemat on käsitletud ja just neid sõnu korrigeeritud või puuduvana märgitud (vrd Rosenplänter 1813b: 20; Anmerkungen 1821: 45). Boubrig peab vajalikuks sõnastada teema kohta kõigepealt uued ja üldistavamad reeglid. (B: 47p-48p)

\subsection{Esimene ja teine infinitiiv [= ma- ja $d a$-tegevusnimi]}

Sissejuhatavalt mainib Boubrig, et 1. infinitiivil on alati aktiivne, põhjustav ning eesmärgi poole pürgiv suunitlus, 2 . infinitiivil aga passiivne ja alistuv (sks leidentlich). Niisiis kasutatakse 1. infinitiivi, kui tegevus või olukord, mida väljendatakse, kujutab endast aktiivset sihti, mille poole iseseisvalt pürgitakse. Just seepärast kasutatakse 1. infinitiivi koos nende verbidega, mille rektsiooniks muidu on daativ või ingressiiv. 2. infinitiivi aga kasutatakse, kui väljendatav tegevus või olukord on otsekui passiivne, juhuslik, alistuv, ilma aktiivse püüdluseta siht. Järelikult pruugitakse 2. infinitiivi seal, kus on vaja väljendada lihtsalt parasjagu eksisteerivat 
oskamist, suutmist, lubatud olemist, saamist, passiivset vastuvõtmist, ihaldamist. Boubrig ütleb, et muidugi pole ühtki reeglit eranditeta ja mõni erand leidub siingi, nt käskma tähistab ju aktiivset tahtmist, kuid ometi on tema rektsiooniks 2. infinitiiv. Mõnikord on tegu siiski vaid näilise erandiga, väidab Boubrig, nt verb tahtma, mis nõuab 2. infinitiivi, ei väljenda aktiivset pürgimust, vaid üksnes kirglikku, kuid passiivset soovi. Seetõttu peaks väljendi Jummala tahtminne asemel õigupoolest ütlema Jummala käsk. Verbi laskma järel on samuti 2. infinitiiv; kuid Boubrigi arvates pole tegu ehteestilise sõnaga, vaid saksa või rootsi keelest laenatuga, mida eestlased esialgu on kasutanud prantsuse sõna laisser tähenduses (ka 'lõdvalt, loiult minna laskma'), seega siis alistuvas, passiivses mõttes. Ka verbi laskma tähenduse 'tulistama' puhul on tegu õigupoolest vaid püssikuke lahtilaskmisega; pr faire'i ('tegema, sooritama, toime panema') aktiivne tähendus on verbile laskma lisandunud alles hiljem, kusjuures vana rektsioon on säilinud, oletab lektor. Ta võrdleb 1. ja 2. infinitiivi vastavalt ladina $u m$ - ja $u$-lõpulise supiiniga. Aktiivse-passiivse tendentsi vastandust demonstreerib ta veel näidetega ta saap sööma'er wird essen, er wird dazu gelangen', ta saap süwwa 'er bekommt essen' ja hirmus üttelda lad 'horrible dictu'. (B: 49-49p, 52) Üsna samamoodi ja samade näidetega on eelnevad seisukohad sõnastatud ka Helleri artiklis, millele Boubrig oma loengutekstis osutab (B: 49, 52; vrd Heller 1822a: 113-115).

Veidi hiljem seletab Boubrig tähenduserinevust väljendite kui ma saan tullema, kui ma saan kirjutama ja kui ma saan túlla, kui ma saan kirjutada vahel. Esimesed kaks näitavad tema meelest üksnes tinglikku võimalikkust: 'wenn es so weit kommt, daß ich komme', 'wenn ich zum Schreiben gelange', järgmised aga tegelikku, füüsilist võimalikkust: 'wenn es möglich ist, zu kommen', 'wenn es möglich ist, daß ich schreiben kann'. Boubrig ütleb, et selle tähelepaneku on teinud Masing Beiträge 15. vihikus $1 \mathrm{k} 49$, kus on juttu ka väljendite tunda sama ja tundma sama erinevusest. Kõnealune kirjutis koosneb tegelikult keeleainelistest märkustest, mis on pärit Masingu kirjadest Johann Heinrich Rosenplänterile; viimane on need lõigud välja kirjutanud ja koos mõne omapoolse lisandusega avaldanud, vt Rosenplänter 1822. (B: 53-53p) 


\subsubsection{Esimene infinitiiv}

Boubrig esitab neli 1. infinitiivi kasutusjuhtu:

1) kui lause subjekt on samal ajal ka infinitiivi subjekt ning alistav verb väljendab vahetut ja kindlat eesmärgipärasust, nt ma lähhä minnema, söma, ellajid tallitama; ma nakka tullema; tulle awwitama; jose tedda kinniwõtma; rahwas iste mahha söma nink tulli ülles mängma; ma tulle kolilatsi kaema;

2) kui lause subjekt on samal ajal ka infinitiivi subjekt ning alistav verb väljendab võimet või olukorda sattumist, nt ma ei kõlba sedda ammetit piddama; ta jäi maggama;

3) kui lause objekt on samal ajal infinitiivi loogiline subjekt, nt ta tahhap minno sõitma 'ta tahab, et mina teda sõidutaks'; aija tedda puid toma; lasse kirst minnema (öeldakse, kui kirst hauda laskmisel takerdub); panne piim kema; ta ạd poija ärra wõrid orjama; minno aijetas minnema; ma panni tedda hobbosid wahtma;

4) kui lause subjekt on aktiivne või tegutsev koos infinitiiviga, nii et infinitiiv sõltub noomenist (substantiivist, adjektiivist või pronoomenist), nt loetama-minnek 'Katechisationsfahrt'; aig om hä mees minnema 'aeg lendab'; temma pä om rassemb wõtma; minnul om poig koli tullema 'mul on poeg, kes peab kooli tulema'; ussin teggema; laisk minnema; ahne söma, joma. (B: 50-50p)

\subsubsection{Teine infinitiiv}

Ka 2. infinitiivi kasutusjuhte on Boubrigil neli:

1) kui lause subjekt on samal ajal ka infinitiivi subjekt, ja verb, millest infinitiiv sõltub, tähistab a) füüsilist või moraalset võimet, $\mathrm{nt}$ ma woi sedda tetta; ma ei tohhi minna; ta julgup wastapanna; sullane-pois ei loppe ramatut oppi; b) ihaldust, soovi, nt kui sa lahhutada tahhat (sellised verbid on tahtma, himmustama, iggatsema, towotama, lubbama, lootma, pelgama); c) püüdlust, mille edu on juhuslik ega olene subjekti kavatsusest, nt allusta sedda tetta; ma lóppeti külwada (sellised verbid on pü̈̈ma, otsma, sõudma, káema jt);

2) kui lause subjekt on infinitiiviga otsekui passiivses suhtes, sellele allutatud või selle objektiks, nt ta mees ei kõlba pitta; temma peap 
tullema kaija 'ta peab tulema ülevaatusele või eksamile'; se jääp mõttelda 'selle peale tuleb veel mõtelda - edaspidi';

3) kui lause subjekt pole infinitiivi suhtes ei subjekt ega objekt, infinitiivi subjekti võiks väljendada saksa impersonaalse man'i abil või on infinitiivi subjektiks possesiivivorm, mis moodustab koos infinitiiviga ladina accusativus cum infinitivo taolise konstruktsiooni, nt ma kässe temmal sedda tetta; lasse täl sedda tetta; ta lask wilja hannel ärrasüwwa; külm wiljal ei anna kaswada; ma lasse seppil sedda tetta; ta ei tija, kuis wäike lạtsiga ümbrekäwwa;

4) kui infinitiiv oleneb noomenist ja a) lause subjekt on infinitiivi suhtes otsekui passiivne objekt, nt se om hä wõtta; se om tarwis osta; se om tetta; mẹs tetta?; se om hä lats sata; ei olle keddagi sata; või b) lause subjekt ei ole ühtlasi infinitiivi subjektiks, nt $m u l$ om meel minna; om lubba, sedda tetta; ei olle aiga kirjotada; täl om nõwwo ('Mittel') kül osta. (B: 50p-51)

Boubrigi sõnul pruugivad eestlased 2. infinitiivi sageli viisil, mida grammatikates seni pole kirjeldatud ega ka saksa autorid oma eestikeelsetes teostes kasutanud. Nimelt kasutatakse kiirel jutustamisel 2. infinitiivi otsekui minevikuvormina; mõnikord aga, kui tundub tegemist olevat ellipsiga (verbid, nagu wõtma, minnema, hakkama jts, oleks nagu välja jäetud), võidakse samamoodi kasutada ka 1 . infinitiivi. Boubrigi meelest on see igal juhul mõjukas võte, mis toob kirjeldusse erilist elavust ja lühidust. Ta ütleb, et esimesena on sellele tähelepanu juhtinud Knüpffer Beiträge 12. vihikus (Boubrig kordab tema seisukohti ja näiteid oma siinses loengutekstis; vrd Knüpffer 1818a: 55). Ta kahetseb, et Knüpffer on esitanud vaid ühe näite, nimelt rahvalaulust ,Söa laul“, mis on avaldatud Beiträge 7. vihikus (vrd Rosenplänter 1817: 48).

Tulli siis wenda jo koddoje,

Minna wennalta küssida:

Wennakenne, ellakenne,

Kas olli söas naene armas,

Naene armas, kasa kallis?

Boubrig märgib, et veidi edasi leidub samas laulus ka rida minna kül wenda õppetama (vrd Rosenplänter 1817: 49), ja arvab, et tegemist ei ole mitte poeetilise vabadusega, vaid võttega, mida kasutatakse ka tavalises proosas. See võimaldab toime tulla ilma sidesõnadeta ja pikkade 
verbaalkonstruktsioonideta, olles üks neid väljendusvahendeid, mis teevad eestlase jutustuse teinekord nii värskeks ning piltlikuks. Lektor võrdleb seda keelevormi ladina infinitivus historicus'ega. (B: 52-53)

Boubrig ütleb, et Masingu teostes leidub veel üks 2. infinitiivi kasutusviis, millest ilmneb selle keelendi otsekui tingimuslik, konditsionaalne loomus: nimelt 2. infinitiiv sidesõna et järel. Lektori sõnul vastab selline konstruktsioon saksa $z u$-ja ladina $u t$-tingimuslausetele ja tuleb põhjaliku keeletundja Masingu teostes ette nii sageli, et seda peab pidama ehteestiliseks. Boubrig esitab näite Masingu raamatust „Täielinne Ristiusso õppetus“ (1826: 8): „.. mehhed, kedda Issand Israéli rahwa seas üllesärratas, et tedda nomida, tedda õppetada, temmale Jummalat, temma tahtmist ja pattustpöörmist, ning ka Kristuse tullemist kulutada.“

\subsection{Veel tegusõnavormidest}

Boubrigi loengute käsikirjas järgnevad nüüd lehed, kus taas lõik-lõigult kommenteeritakse Hupeli grammatikas verbi käändeliste vormide süntaksi kohta öeldut (B: 53p-55; vrd H: 136-139). Kui võrrelda Boubrigi käsikirja seda osa Moritza konspekti vastavate lehtedega (60-63), siis selgub, et Boubrigi mitme lühida servamärkuse taga on tegelikult Helleri manuskript (vrd Heller 1829), mille teatud lõike Boubrig on loengus nähtavasti kasutanud otse, kirjutamata neid enne ümber oma loengukäsikirja. Helleri ja Boubrigi süntaksikäsikirju tasub põhjalikumalt võrrelda eraldi kirjutises. Seetõttu Boubrigi loenguteksti seda osa praegu lähemalt ei vaadelda. Igal juhul leidub siingi lisanäiteid, vigade parandusi, täpsustusi, viiteid kaasaegsele keeleliteratuurile jne.

Loengute järgmises osas vaatleb Boubrig mitmesuguste verbivormide tarvitamist. Esmalt arvustab ta mõnd Masingu seisukohta. Ta juhib tähelepanu sellele, et Beiträge 5. vihikus on Masing kirjutanud, et koos abiverbiga moodustatud perfectum compositum'i tuleks kasutada refereeringu puhul ja üksnes mineviku partitsiibi abil moodustatavat perfectum historicum'i siis, kui jutustatakse midagi iseenda poolt. Nii on Masing tõepoolest väitnud, analüüsides Peter Heinrich von Frey tõlketöös üht lauset, mille on öelnud Aleksander I oma manifestis Napoleoni kohta: „Ei ühtegi polle tedda woinud keelda kange meelega aiamast, mis ta kawwalaste olli noudnud" (Frey 1813: 83). Masing on soovinud, et lause algus olnuks Ei üksgi tedda woinud keelda .. (vrd Masing 1816b: 83). Boubrig 
on aga märganud, et Beiträge 13. vihikus on Masing kritiseerinud lauset Nenda on ikka need willetsaks saand, kes kässo õppetussest tagganesid. Masing on öelnud, et tegemist on refereeringuga, mistõttu viimane sõna peaks olema tagganend (vrd Rosenplänter 1821: 139-140). Boubrig leiab, et need seisukohad on vastuolulised. Ka on Masing samas väitnud, et lause lõpul tuleks kasutada $n d$-, mitte $n u d$-vormi. Siingi on Boubrig märganud, et Masingu oma tekstides leidub kontraheerunud vormi mujalgi kui lause 1õpul. Ka peab Boubrig eksitavaks ja kirjakeelde sobimatuks Masingu tekstides leiduvaid eitavaid, ilma eitussõnata vorme, nt usuõpetusraamatus (Masing 1826:11) lauses et ükski kulutuse sõnna rõõmsam woi olla, kui jne. (B: 55-56p)

Boubrigi järgi ei ole saksa konjunktiivi vasteks eesti keeles optatiiv [= tingiv kõneviis]; ta esitab neli võimalust selle tähenduse väljendamiseks: 1) indikatiiv koos sidesõnaga et, nt ta ütleb, et ma ollen; 2) indikatiiv koos abiverbina kasutatud tegusõnaga piddama, nt ta ütleb, et ma pean ollema; 3) partitsiibikonstruktsioon, mis on ladina accusativus cum infinitivo sarnane (kuid mitte sama kui see), nt ta ütleb, tedda haige ollewat; 4) teatud juhtudel formatiiv [= saav kääne], nt tln ta tunnistab ennast õigedaks, trt ta kittap henda õiges 'er rühmt von sich, daß er rechtschaffen sey'.

Väga huvitavaks kiidab Boubrig Beiträge 13. vihikus leiduvat Petersoni artiklit eesti verbilõppudest (Peterson 1821). Boubrig ütleb, et artikkel puudutab küll rohkem vormiõpetust, aga on genuiinse eestlase uurimusena kahevõrra põnev. (B: 56p-57)

\section{9. Üksikmärkusi sõnade ja lausete ühendamise kohta}

1829. aasta kevadsemestri süntaksiloengute viimase peatüki on Boubrig pealkirjastanud „Einige einzelne Bemerkungen über die ehstn. Construction. Einiges über die Verbindung der Worte und Sätze in der ehstnischen Sprache“ („Mõned üksikmärkused eesti keele ehituse kohta. Üht-teist sõnade ja lausete ühendamisest eesti keeles“; B: 57p). Hupeli grammatika süntaksiosa viimase peatükiga „Von etlichen Idiotismen“ („Mõnedest väljenditest"; H: 139-144) see enam ei haaku. 


\subsection{Adjektiivse täiendi paiknemine}

Boubrig räägib adjektiivi paiknemisest relatiivis [= omastavas] oleva täiendi ees või järel, viidates seejuures Knüpfferi Beiträge-artiklile, kust see lõik koos näidetega võetud on (vrd Knüpffer 1815: 122-123). Kui adjektiiv käib nii subjekti kui ka selle täiendiks oleva relatiivis sõna kohta tervikuna, siis paigutatakse adjektiiv relatiivivormi ette, nt ustawad Jesusse Jüngrid, s.t ustawad käib kõigi jüngrite kohta; kuid Jesusse ustawad Jüngrid 'need Jeesuse jüngritest, kes on ustavad'. Samasugused näited on kadduw ma-ilma rõõm ja ma-ilma kadduw rõõm; armsam issa poeg 'selle (mitte mõne teise) isa armsaim poeg' ja issa armsam poeg 'see isa poeg, kes on talle armsaim'. (B: 57p-58)

\subsection{Kuidas kasutada sõna omma}

Seejärel on Boubrig rääkinud sõna omma kasutamisest (B: 60-61; vrd ka Moritz: 64), muutes märkusega (vt B: 58) tekstilõikude järjekorda. Ta ütleb, et algajatele on selle sõna kasutamine raske, sageli aetakse see segi sõnadega sinna, temma jts, umbes samamoodi, nagu juhtub ladina sõnadega ejus ja tuus, suus jts. Boubrig arvab vigade põhjuseks selle, et sõna omma käsitatakse alati üksnes pronoomenina, kuigi tegu on hoopis puhtakoelise adjektiiviga ladina tähenduses 'proprius', saksa 'eigen'. Et eesti keeles puudub õige possessiivpronoomen, siis kasutatakse selle asemel sõna omma ja vahel olenevalt vajadusest ka sõnu sinno, temma jts. Reegel on Boubrigi meelest lihtne: sõna omma tuleb kasutada siis, kui saksa lauses olevad possessiivpronoomenid mein, dein, sein jts käivad subjekti [= tegija, agendi] kohta; muidu tuleb kasutada sõnu minno, sinno, temma jne, nt tedda ajeti omme teopäiwi teggema 'man trieb ihn an, seine Frohntage zu thun'; kõige rịstiinnimesse kohhus on omma liggimest armastada; meil sünnib ikka omma lotust Jummala peäle panna; minnult küssitti omma poega rekrutiks anda. Boubrig meenutab, et subjekt ei ole alati selgelt väljendatud, vaid võib olla juurdemõeldav eelmise lause põhjal või ka verbi põhjal. Peale selle kasutatakse omma ka nimisõnana tähenduses 'der, die, das Eigne', nt temmalt wõeti kõik omma ärra; adjektiivina, kusjuures vahel isegi seal, kus seda vaja poleks, pleonastiliselt, nt sawad ommaks põrmuks 'sie werden zu ihrem Staube'. Siia lisab Boubrig loendi Beiträge omma-käsitlustest koos lühidate kommentaaridega: kõigepealt tuleb tema sõnul 2. vihik, lk 78 (vrd Rosenplänter 1813c); siis poleemikat 
ja parem reegel 3. vihikus $1 \mathrm{k} 125 \mathrm{jj}$ (vrd anonüümse autori artikkel Wann 1814: 125-127, kust ongi pärit Boubrigi siinne põhireegel koos näidetega); veel täielikum selgitus leidub Boubrigi meelest 15. vihikus 1k $136 \mathrm{jj}$ (vrd Heller 1822b: 136-137), kust lektor on võtnud ülejäänud osa siinsest esitusest. Nagu Heller seal, nii pole ka Boubrig rahul Beiträge 13. vihikus leiduva kirjutisega, kus on üpris põhjalikult käsitletud omma ühildumist põhisõnaga. Nimelt vahendab Rosenplänter seal Masingu praegugi üpris meelevaldsena tunduvat reeglit ja rohkeid näiteid, mille järgi omma ühildub oma põhisõnaga käändes ja arvus üksnes ainsuse seesütlevas, seestütlevas ja alalütlevas ning mitmuse nimetavas (vrd Rosenplänter 1821: 143-150). Oma seisukoha noomenite, sh omma ühildumise asjus oli Boubrig üliõpilastele esitanud juba varem (vt siin punkt 4).

\subsection{Jaatav lause: kas ning või ja?}

Jaatavate lausete ühendamisel on Boubrigi sõnul kõige tavalisemad sidesõnad ning (trt nink) ja ja. Nende sidesõnade tähenduserinevust seletades toetub ta kahele Beiträge kaastöölisele. Petersoni järgi tuleks sidesõna ning kasutada siis, kui asjad toimuvad korraga, nt ta olli surelinne, ning lubbas; siis, kui üks asi järgneb teisele, sobib ja, nt karro tulli ta jure, ja ütles (vrd Peterson 1818a). Boubrigi arvates on asja tuuma paremini tabanud Masing, kelle seisukoha ta Rosenplänteri artikli vahendusel esitab: ja on vaid copulativa; sidesõna ning aga on 1) continuativa, mille saksa tähendused on 'denn, desgleichen, imgleichen [sest, samamoodi, samuti]'; 2) causalis, sks 'daher, demnach [seetõttu, seepärast]'; 3) illativa ('esile kutsuv, tekitav'), sks 'daher, indem, weil, demnach [sellest tulenevalt, selle läbi et, sest et, järelikult]', nt Temma ep olle ialgi maenitsust wõtnud, egga nomimisest holind - ning et ta sesuggune olnud, on ta nenda hukka läinud (vrd Rosenplänter 1822: 55). (B: 58)

\subsection{Eitava lause sidesõnad}

Boubrigi arvates on suur viga siduda eitavaid lauseid ja või ning abil. Ta esitab kõigepealt neli reeglit, öeldes, et need on sõnastatud Beiträge 10. vihikus lk 66 jj ilmunud Masingu kirjutise põhjal:

1) kui lause eitavad osad kuuluvad ühte lauseperioodi, tuleb nad eraldada adversatiivsete või disjunktiivsete sidesõnade abil, milleks 
tavaliselt on egga või ehk; kui aga järgneb veel kolmaski eitav lause, liidetakse see ei ka või egga abil, nt Kes pattust ei põra, egga ei ussu;

2) kui lauseperioodis on kõigepealt eitav(ad) lause(d) ja sellele järgneb (järgnevad) jaatav(ad) lause(d), siis tuleb eitava ja jaatava poole vahele panna waid, nt Kõigile, kes pattust ei põra, egga ussu, waid, kes melega patto sisse jäwad, ja maenitsust põlgwad;

3) kui aga eelmisel juhul on tegemist tingimuse või järeldusega, tuleb kasutada tingimuslikku sidesõna siis, nt Kui temma õppetust ei wõtta, egga nomimissest tahha holida: siis lass katsub (või katsuda) kuida eddasi saab;

4) kui teineteisele järgnevates eitavates lausetes subjekti või selle asemel olevat pronoomenit ei korrata, jääb teine eitus ära, muidu tuleb eitust korrata, nt kui temma õppetust ei wõtta, egga nomimissest tahha holida, vrd kui temma õppetust ei wõtta, ehk kui temma nomimissest ei tahha holida (vrd Masing 1818: 67-68).

Viienda reegli on Boubrig formuleerinud Masingu piiblilooraamatu põhjal:

5) saksa tähendust 'anders nicht .. als nur' antakse ehtsas eesti keeles edasi nii, et esimeses pooles on mu wisiga ei või mitte, teises pooles muud kui agga (vrd Masing 1824b: 5). (B: 58p-59)

\subsection{Miks, ommeti ja nü̈̈d}

Sõna miks puhul hoiatab Boubrig: seda ei tohi kasutada järeldava või põhjusliku sidesõnana saksa tähenduses 'weshalb, weswegen, wozu [kuna, mistõttu, milleks]' jts, sest miks on vaid küsisõna, sks 'warum?', 'weswegen?'. Ta lisab viite kahele Beiträge artiklile, milles on esitatud sama seisukoht (vrd -t 1815: 127; Masing 1816b: 44). Sõna ommeti saksa vaste ei ole Boubrigi väitel mitte 'doch', vaid 'dennoch, dessenungeachtet [siiski, sellele vaatamata]', seetõttu on tema meelest vale öelda tulle ommeti!. Saksa 'doch' väljendamiseks peaks kasutama sõnu kül või nüüd, nt tulle kül!, katsu nü̈̈d!; mõnikord (ootuse või nõuande puhul) sobiks ka $i k k a$, nt tulle ikka hommen!. Veenmiseks või kohustamiseks aga kõlbab kõige paremini lause ees asetsev et, nt et tulle!, et katsu!, et minne!. Kui on tegemist imestamisega, siis sobib ka ommeti, kuna siis on saksa 'doch' ja 'dennoch' samatähenduslikud, nt temma on ommeti taggasi tulnud! Ka nende väidete juurde on Boubrig lisanud viite kahele Beiträge 6. ja 
10. vihikus ilmunud artiklile (vrd Luce 1816; Hirschhausen 1818), kust ongi pärit tema siinsed seletused ja näited. Boubrigi soovitus kasutada sõna nü̈̈d üksnes tähenduses 'jetzt', mitte aga 'nun', tundub praegu päris juuksekarva lõhkiajamisena, sest nüüdne sõnaraamatutähendus näib neil saksa sõnadel olevat enam-vähem ühesugune. See nõuanne on esmalt sõnastatud Beiträge 1. vihikus (Rosenplänter 1813a: 20-22), millele Boubrig ka viitab. (B: 59-60)

\section{Kokkuvõtteid ja järeldusi}

Oma süntaksiloengute koostamisel on Johann Samuel Friedrich Boubrig lähtekohaks võtnud August Wilhelm Hupeli „Ehstnische Sprachlehre“ 2. väljaande (1818), mille lauseõpetusosa (lk 121-144) ta lõik-lõigult vaatleb, kritiseerib, kommenteerib ja täiendab. Loengukeel on mõistagi saksa keel, keelenäiteid esitab Boubrig nii tallinna- kui ka tartukeelseid (viimaseid on siiski rohkem). Tollases vaidluses ühise eesti kirjakeele loomise asjus asus Boubrig mõõdukal positsioonil: nii tallinna kui ka tartu keel on eesti keel, aeg näidaku, missuguseks kujuneb ehtne eesti ühiskirjakeel. Tartu ülikooli tolleaegsed eesti keele loengud olid mõeldud eelkõige teoloogiaüliõpilastele, kes oma tulevases pastoriametis pidid eesti keelt oskama nii kõnes kui ka kirjas. Suurem osa XIX sajandi algupoole Tartu teoloogiaüliõpilastest olid pärit Eesti- või Liivimaalt. Eesti keele varasem oskus oli neil kõikuv, kuid enamasti siiski olemas. Seevastu väljastpoolt Eesti ala tulnud tavaliselt eesti keelt ei osanud (oli ka erandeid, nagu Boubrig ise või Kristian Jaak Peterson, mõlemad pärit Riiast). Boubrigi loenguid hoolsalt konspekteerinud üliõpilane, Liivimaa pastorisuguvõsast pärit Wilhelm Julius Moritz tõenäoliselt oskas eesti keelt ex usu juba enne oma stuudiumit.

Boubrig ei olnud arvatavasti oma eesti keele oskuses lõpuni kindel, kuid püüdis oma teadmisi hoolsalt täiendada, muu hulgas ka oma sõbra, Räpina pastori ja aktiivse eesti keele uurija Johann Friedrich Helleri abil ja toetusel. Ka oma süntaksiloengute koostamisel on Boubrig kasutanud Helleri uurimusi, peale ajakirjas Beiträge ilmunute ka Helleri käsikirjalist materjali. Helleri käsikirjalistele märkustele (Heller 1829) ta oma loengutes ei viita. Nende märkuste suhet Boubrigi loengutekstiga siinses artiklis detailsemalt ei analüüsitud, kuid edaspidi väärib see käsitlemist. Lisaks on Boubrig kasutanud rohkesti teiste oma kaasaegsete (O. W. Masing, 
A. F. J. Knüpffer, J. H. Rosenplänter jt) Beiträges ja mujal ilmunud keelekirjutisi ning neile ka viidanud, suunates nii oma üliõpilasi tollase erialakirjanduse juurde. Beiträge uurimuste, Helleri ja Knüpfferi tööde kaudu on tema loengutes ka soome keeleteadusliku mõtte mõjusid. Muu hulgas leiab kiitvat mainimist ta kaasmaalase, Kristian Jaak Petersoni Beiträge-kaastöö, mille puhul Boubrig märgib ära Petersoni eesti päritolu, Tartus studeerimise ning kahetseb Petersoni varast surma.

Igal juhul õpetati eesti keelt tolleagses Tartu ülikoolis sihtkeelena, mitte emakeelena. Nullist algajatele (kui neid oli) tundub Boubrigi loengute sisu olevat olnud küll üpris nõudlik. Tegemist on eesti keele õpetamisega teoreetiliselt, akadeemilisel kõrgtasemel, tollase keeleteaduse saavutustele toetudes. Siiski lähtutakse praktilisest keelekasutusest ning eesti-saksa kontrastiivsest vaatepunktist, kusjuures on märgata ka pürgimust normatiivsusele.

Ei Hupelilt ega ka Boubrigilt pole leida nt määratlusi lauseliikmete olemuse kohta, sest see teadmine on otsekui aprioorne, omandatud eelnenud klassikalise gümnaasiumihariduse käigus. Küll aga on Boubrigi puhul selgelt märgata püüet sõnastada esmalt keelest tuletatud üldisi seaduspärasusi ning jälgida siis nende avaldumist praktilises keelekasutuses. Ta ise nimetab oma meetodit filosoofiliseks keeleuurimiseks ning suhtub kriitiliselt sellisesse keelemehetegevusse, mis ei lähtu keelefilosoofiast, vaid sõnastab paindumatuid reegleid paljude üksikute keelenähtuste kohta.

Hupeli väidet, mille kohaselt eesti keele süntaks sarnanevat teiste Euroopa keelte süntaksiga, peab Boubrig ebaõigeks: soome sugukeelte hulka kuuluva eesti keele süntaks erineb vanade ja uute keelte süntaksist vägagi palju. Üllataval kombel toob Boubrig aga mitmel korral esile sarnaseid jooni eesti ja prantsuse süntaksis. Selles võrdluses võime näha nii pedagoogilist võtet kui ka soovi parandada eesti keele mainet: saksa keele ja tollase peene kultuurkeele prantsuse keele erinevused pidid õppuritele teada olema; võrreldes nüüd eesti keelt prantsuse keelega, oli hõlpsam omaks võtta ka eesti ja saksa keele erinevusi. Muidugi on Boubrig eesti keelt võrrelnud ka saksa ja ladina keelega, needki olid üliõpilaste jaoks tuttavad ja kõrge staatusega keeled.

Palju tähelepanu on Boubrig oma süntaksiloengutes pööranud neile eesti keele seikadele, mis on saksa keelest erinevad: arvsõnade kasutamine, eitus, käändesüntaks (eriti objekti käänded), infinitiivide ja kesksõnade tarvitamine, sõnade järjekord lauses jms. Leidub ka pikemaid arutlusi, kus 
on loobutud Hupeli grammatika järgimisest. Näiteks käändesüntaksi puhul kirjeldab Boubrig kõigepealt eesti keele kolme esimest käänet, mida ta Helleri eeskujul (too oli Beiträge 15. vihikus 1822 ja 16. vihikus 1823 avaldanud vastavad artiklid) nimetab definitiiviks, relatiiviks ja indefinitiiviks, võttes aluseks definiitsuse-indefiniitsuse põhimõtte. Ta kirjeldab ka teiste eesti käänte funktsioone, eriti väliskohakäändeid ja sisekohakäänetest sisse- ja seestütlevat. Tavaliselt esitab ta kõigepealt ühe või teise kaasuse kasutamise põhireegli ja seejärel käändefunktsioonide lähemad ülevaated. Eesti keele näited, mida Boubrig oma loengutes esitab, on sageli üles märgitud rahvasuust, aga pärinevad ka vaimulikust või erialakirjandusest. Esituslaad on deskriptiivne (,meie eestlane räägib nii“), aga ka normatiivne (,see on halb, saksapärane, madalkeelne, see pole ehtne eesti keel, rahvas küll räägib nii, aga rikutud kirjakeele mõjul“"). Boubrig rõhutab korduvalt eesti keele omapära ja eesti keele põhjalikuma uurimise vajadust. Tema ülikooliloengutes kajastub tollane eesti keeleteaduslik mõte: vilgas, otsiv, eesti keelt väärtustav, uuenduslik ja poleemiline.

\section{Lühendid $^{3}$}

f - fond; $\mathrm{m}$ - mapp; $\mathrm{p}$ - pöördel; tln - tallinna kirjakeel, tallinna dialekt; trt - tartu kirjakeel, tartu dialekt; piibliraamatute lühendid: Ap - Apostlite teod; Ef - Pauluse kiri efeslastele; Jh - Johannese evangeelium; Js - Jesaja raamat; $1 \mathrm{Kr}$ - Pauluse esimene kiri korintlastele; Lk - Luuka evangeelium; Mt - Matteuse evangeelium; $\mathrm{Rm}$ - Pauluse kiri roomlastele; 1Tm - Pauluse esimene kiri Timoteusele

\section{Kirjandus}

Anmerkungen $1821=$ Anmerkungen zu Hupels ehstnischer Sprachlehre. Beiträge 13, 28-46.

Antwort 1826 = Antwort auf die im 5ten Hefte S. 172 befindliche Frage: wie unterscheiden sich die beiden Ablative? - Beiträge 18, 155-156.

Ariste, Paul 1979. Johann Samuel Friedrich Boubrig. - Tartu ülikooli ajaloo küsimusi VII. TRÜ ajaloo komisjoni materjalid. Tartu: Tartu Riiklik Ülikool, 42-51.

$\mathbf{B}=[$ Johann Samuel Friedrich Boubrig 1829]. Zur Syntax der ehstnischen Sprache. Größtentheils in Folge der Angaben in Hupels Grammatik, 2te Ausg. von S. 121 an. [Käsikiri.] KM EKLA, f 192, m A 171: 23.

Beiträge $=$ Beiträge zur genauern Kenntniss der ehstnischen Sprache.

3 Esitatud on üksnes need lühendid, mida aastaraamatu lühendinimestikus pole. 
Frey, Peter Heinrich von 1813. Allerhöchstes Manifest, datirt Wilna den 25. December 1812. Jummala armust Aleksander se Essimenne, keige Wenne-rigi Keiser ja Issewallitseja, annab Omma trui allamattele teäda. Beiträge 1, 82-88.

$\mathbf{H}=$ August Wilhelm Hupel 1818. Ehstnische Sprachlehre für die beyden Hauptdialekte, den revalschen und dörptschen; nebst einem vollständigen ehstnischen Wörterbuche. Zweyte durchgängig verbesserte und vermehrte Auflage. Mitau: Steffenhagen.

Heller, Johann Friedrich 1822a. Anmerkungen zum XIII. Heft dieser Beiträge. Beiträge 15, 74-124.

Heller, Johann Friedrich 1822b. Parallel-Anmerkungen zu den ehstn. PredigtDispositionen im XII. Heft. S. 135-168. - Beiträge 15, 130-149.

Heller, Johann Friedrich 1822c. Versuch über das Wesen und den Gebrauch der ehstn. Casen, besonders des sogenannten Nominativs, Genitivs und Accusativs. - Beiträge 15, 1-42.

Heller, Johann Friedrich 1823. Nachtrag zu dem Versuche über das Wesen und den Gebrauch der ehstn. Casen, im 15ten Hft. dieser Beiträge. - Beiträge $16,11-27$.

H[eller, Johann Friedrich] 1829. Bemerkungen zu der Syntax in Hupels ehstnischen Grammatik, 2e Ausgabe. [Käsikiri.] KM EKLA, f 192, m A 195: 17.

Hirschhausen, Jacob Johann Anton 1818. Welches ehstnische Wort entspricht der deutschen Conjunction „doch“? (In Beziehung auf die im VI. Heft dieser Beiträge pag. 53 gemachten Vorschläge.). - Beiträge 10, 91-95.

Knüpffer, Arnold Friedrich Johann 1815. Sprach- und andere Bemerkungen über einige im ersten, zweiten und dritten Hefte dieser Beiträge enthaltenen ehstnischen Aufsätze, Worterklärungen u. s. w. - Beiträge 4, 103, 114-124.

Knüpffer, Arnold Friedrich Johann 1817. Bemerkungen über die Declinationsund Casusformen der Ehstnischen Sprache. Dem Herrn Doctor der Theologie, Probst und Consistorial-Assessor David Gottlieb Glanström, zur Jubelfeyer des fünfzigsten Jahresfestes seiner Predigeramts-Führung, an den Kirchen zu Weissenstein und St. Annen, den 13ten Juny 1817. Als Beweis seiner Verehrung gewidmet von A. F. J. Knüpffer, ConsistorialAssessor und Prediger zu St. Cathrinen. Reval: Johann Hermann Gressel.

Knüpffer, Arnold Friedrich Johann 1818a. Anmerkungen zu dem siebenten Hefte dieser Beiträge. - Beiträge 12, 47-77.

Knüpffer, Arnold Friedrich Johann 1818b. Ueber misse, missest und misseks. Beiträge 12, 24-33.

Laanekask, Heli 1988. Wilhelm Friedrich Steingrüber tartu keele eluõiguse kaitsjana. - Keel ja Kirjandus 10, 585-593. 
Laanekask, Heli 2003. Johann Samuel Boubrigi kiri Karl Gottlob Sonntagile. 200 aastat eesti keele ülikooliõpet. 1803 eesti ja soome keele lektoraat Tartu ülikoolis. Juubelikogumik. Koost. Valve-Liivi Kingisepp. Toim. Mati Erelt, Tiiu Erelt. (= Tartu Ülikooli eesti keele õppetooli toimetised 25.) Tartu: Tartu Ülikool, 61-87.

Laanekask, Heli 2007. Specimen eruditionis ehstonicae. - Merkityksen ongelmasta vähemmistökielten oikeuksiin. Juhlakirja professori Helena Sulkalan 60-vuotispäivänä. Toim. Harri Mantila, Merja Karjalainen, Jari Sivonen. (= Acta universitatis Ouluensis. B, Humaniora 79.) Oulu: Oulun Yliopisto, 125-142.

Laanekask, Heli 2013. Viron kieli toisena kielenä -opetuksesta Tarton yliopistossa 1820-luvun lopulla. - Lähivõrdlusi. Lähivertailuja 23. Toim. Pirkko Muikku-Werner, Johanna Laakso, Katre Õim, Maria-Maren Sepper. Tallinn: Eesti Rakenduslingvistika Ühing, 148-162.

Luce, Johann Wilhelm Ludwig von 1816. Ommeti für doch. - Beiträge 6, 53-54. Masing, Otto Wilhelm 1816a. Ehstnische Originalblätter für Deutsche. Dorpat: J. C. Schünmann.

Masing, Otto Wilhelm 1816b. Uebersetzung des Manifests aus Wilna vom 25sten December 1812., vom Herrn Consistorial-Assessor und Pastor von Frey. - Beiträge 5, 37-50. ${ }^{4}$

Masing, Otto Wilhelm 1818. Beitrag zur Kritik der ehstnischen Sprache und Literatur. - Beiträge 10, 60-71.

Masing, Otto Wilhelm 1824a. Beitrag zur Ehstnischen Orthographie. Dorpat: J. C. Schünmann.

Masing, Otto Wilhelm 1824b. Wiiskümmend kaks Luggemist Uest-Testamendist wäljawallitsetud, kuhhu küssimisi, mis järrelemõtlemist tahtwad, häid õppetusi, ja pühha kirja salmisi jurepandud, mis Otto Willem Masing nore rahwa ja kolilaste heaks wäljaandnud. Perno: J. G. Marquardt.

Masing, Otto Wilhelm 1826 [tiitellehel 1825]. Täieline Ristiusso õppetus, mis targema rahwa ja koolmeistrite kassuks wäljaandnud Otto Willem Masing. Perno: Kottart Markwardi kirjadega.

Masing, Otto Wilhelm 1827. Beleuchtung der, über O. W. Masing's Beitrag zur ehstnischen ortographie, erschienenen Bemerkungen, vom Verfasser des Beitrages zur ehstnischen Orthographie. Pernau: G. Marquardt.

Moritz = Wilhelm Julius Moritz 1828-1829. Ehstnische Sprachlehre. [Käsikiri.] KM EKLA, f 192, $\mathrm{m}$ A 78.

OWM registrid $=$ Otto Wilhelm Masingu kirjad Johann Heinrich Rosenplänterile 1814-1832. Registrid. 1997. Koost. Eva Aaver, Heli Laanekask, Kristi Metste, Abel Nagelmaa. Tartu: Eesti Kirjandusmuuseum.

Peterson, Kristian Jaak 1818a. ning und ja. - Beiträge 12, 150.

${ }^{4}$ See Masingu artikkel ilmus nimemärgi $\mathrm{a}+\mathrm{b}$ all. Vt lähemalt OWM registrid: 7. 
Peterson, Kristian Jaak 1818b. Ueber den Gebrauch der beiden Ablative im Ehstnischen. - Beiträge 12, 148-149.

Peterson, Kristian Jaak 1818c. Ueber den Gebrauch des Nom. Gen. und Acc. bei einem Verb. Act. - Beiträge 12, 145-148.

Peterson, Kristian Jaak 1821. Etwas über die Verbal-Endungen der ehstnischen Zeitwörter. - Beiträge 13, 93-94.

Piibel 1739 = Piibli Ramat, se on keik se Jummala Sanna, mis pühhad Jummala Mehhed, kes pühha Waimo läbbi juhhatud, Wanna Seädusse Ramatusse Ebrea Kele ja Ue Seädusse Ramatusse Kreka Kele essite on ülleskirjotanud, nüüd agga hopis, Jummala armo läbbi, meie Eesti-Ma Kele Essimest korda üllespandud .. . Tallinn: Jakob Joan Köler.

Renvall, Gustaf 1815-1817. Dissertatio academica de signis relationum nominalium in lingua fennica. Aboae: typis Frenckellianis.

Rosenplänter, Johann Heinrich 1813a. Germanismen. - Beiträge 1, 20-23. ${ }^{5}$

Rosenplänter, Johann Heinrich 1813b. Syntactische Regeln. - Beiträge 1, 20.

Rosenplänter, Johann Heinrich 1813c. Wann das Pronomen omma stehen muß. - Beiträge 2, 78-79.

Rosenplänter, Johann Heinrich 1817. Poesien der Ehsten. Erste Sammlung des Herausgebers. - Beiträge 7, 32-87.

Rosenplänter, Johann Heinrich 1818. Bemerkungen über die Declinationsund Casusformen der Ehstnischen Sprache [...] von A. F. J. Knüpffer, Consistorial-Assessor und Prediger zu St. Catharinen. Reval, gedruckt bey Joh. Herrm. Gressel. 12 S. 4. [Arvustus.] - Beiträge 12, 135-139.

Rosenplänter, Johann Heinrich 1821. Anmerkungen von Herrn Ober-Consistorial-Ass. O. W. Masing zu einigen ehstnischen Predigt-Dispositionen des Herausgebers. - Beiträge 13, 133-168.

Rosenplänter, Johann Heinrich 1822. Acht und sechzig gelegentliche Sprachbemerkungen aus Briefen des Herrn Propsts, Ober-Consistorial-Assessors und Ritters O. W. Masing. Gesammelt und nebst einer Bitte mitgetheilt von dem Herausgeber. - Beiträge 15, 42-61.

Sjögren, Andreas Johan 1821. Ueber die finnische Sprache und ihre Literatur. St. Petersburg: N. Gretsch.

[Steingrüber, Wilhelm Friedrich] 1825. Giebt es wirklich eine bestimmte und unbestimmte Declination in der ehstnischen Sprache, und sind wohl alle Vorschläge, die ehstnische Orthographie betreffend, annehmbar? Beiträge 17, 1-25.

5 Rosenplänter on oma Beiträge artiklid enamasti avaldanud endale kui ajakirja väljaandjale viitavate nimemärkide all, nt v. H. (= von Herausgeber), d. H. (= der Herausgeber) jts, mida siinses kirjanduse loetelus ei edastata. 
[Steingrüber, Wilhelm Friedrich] 1826. Bemerkungen über O. W. Masing's Beitrag zur ehstnischen Orthographie. Von einem Freunde der ehstnischen Sprache. Pernau: J. G. Marquardt.

Stråhlmann, Johann 1816. Finnische Sprachlehre für Finnen und Nicht-Finnen, mit Beziehung auf die Aehnlichkeit der finnischen Sprache mit der ungarischen, und einem Anhange von finnischen Idiotismen und Vergleichung der finnischen und ungarischen Etymologie, mit einem Auszuge in diesen Sprachen verwandter Wörter. St. Petersburg: M. C. Iversen.

Zur Syntax = Zur Syntax der ehstnischen Sprache. Größtentheils in Folge der Angaben in Hupels Gramatik, 2te Ausg. von S. 121 an. an den verstorb. Propst Heller, zu Rappin. [Käsikirjakogum.] KM EKLA, f 192, m A 79. -t. 1815. [Der Herr Consistorial-Assessor von Frey ..]. - Beiträge 4, 124-129.

Ueber 1815 = Ueber den gebrauch der beiden Dative. - Beiträge 4, 172-180.

UT 1815 = Meije Issanda Jesusse Kristusse Uus Testament Ehk Jummala Ue Sädusse Sanna mis Pärrast Issanda Jesusse Kristusse Sündmist pühhast Ewangelistist ja Apostlist on ülleskirjotud, ja nüüd Ma Kelel üllespantud Tallinnas. Tallinn: Johan Kristow Prendeken.

Wann 1814 = Wann das Pronomen omma stehen muß. - Beiträge 3, 125-127.

Wiedemann, Ferdinand Johann 2011. Eesti keele grammatika. Tlk. Heli Laanekask. Toim. Ellen Niit. Tallinn: Eesti Teaduste Akadeemia Emakeele Selts.

WT 1821 = Meije Issanda JEsusse Kristusse Wastne Testament, ehk Jummala Pühha sönna, kumb perrast Issanda JEsusse Kristusse sündmist pühhist ewangelistist nink apostlist om ülleskirjotetu. Tarto piibli-koggodusse nouga trükkitu Mitau linan Peters-Steffenhageni man.

\section{Arhiivimaterjalid}

KM EKLA = Eesti Kirjandusmuuseumi Eesti kultuurilooline arhiiv. 


\title{
Johann Samuel Friedrich Boubrig's lectures on syntax at the University of Tartu
}

\author{
HELI LAANEKASK
}

The article gives a detailed overview of the lectures on Estonian syntax delivered by Johann Samuel Friedrich Boubrig, Estonian language lecturer at the University of Tartu, in the spring semester of 1829 . The description of the content of the lectures is based on the manuscripts of the lectures and several other archive materials stored in the Estonian Cultural History Archives at the Estonian Literary Museum. The article also takes a look at the linguistic literature related to the lectures, particularly the syntax chapter in August Wilhelm Hupel's Ehstnische Sprachlehre (1818), articles in the journal Beiträge zur genauern Kenntniß der ehstnischen Sprache, and other publications.

At that time, the Estonian language was taught at the University of Tartu as a target language, not as a mother tongue, with German as the source language of teaching. Boubrig built up his lectures on syntax as comments to the syntax part in Hupel's Ehstnische Sprachlehre; he corrects or supplements Hupel, presents additional examples and refers to contemporary linguistic literature. First, Boubrig attempts to formulate general regularities derived from the language and then to watch their manifestations in actual usage. He calls his method philosophical linguistic research and is critical of linguists who do not rely on the philosophy of language but formulate inflexible rules about many isolated phenomena in language.

Boubrig disputes Hupel's statement that Estonian syntax is similar to other European languages and says the syntax of Estonian, as one of the Finnic languages, differs greatly from the syntax of ancient and modern languages. Boubrig does not present parallels with other Finno-Ugric languages in his lectures, but he compares Estonian syntax with German, French and Latin. As these languages were familiar to students and enjoyed the status of highly cultured languages, we can regard these comparisons as an educational device with the wish to enhance the prestige of the Estonian language.

There is a strong German-Estonian contrastive approach. Boubrig discusses in greater detail numerous features of Estonian that differ from German: use of numerals, negation, case syntax (particularly object cases), use of infinitives and participles, word order, etc. The Estonian examples that Boubrig presents in his lectures have often been recorded from word of mouth but also from religious 
or linguistic literature. The manner of presentation is descriptive and normative. Boubrig repeatedly emphasises the peculiarity of the Estonian language and the need for deeper study of it. His university lectures reflect the contemporary linguistic thought in Estonia: agile, searching, valuing the Estonian language, innovative and polemical.

Keywords: history of research of the Estonian language, history of literary Estonian, Estonian as a target language, Estonian syntax, Estonian morphosyntax

Heli Laanekask

eesti ja üldkeeleteaduse instituut

Tartu Ülikool

Jakobi 2

51014 Tartu

heli.laanekask@ut.ee 